\title{
CEsifo WORKING

\section{Gathering Support for Green Tax Reform: Evidence from German Household Surveys}

Frederick van der Ploeg, Armon Rezai, Miguel Tovar 


\section{Impressum:}

CESifo Working Papers

ISSN 2364-1428 (electronic version)

Publisher and distributor: Munich Society for the Promotion of Economic Research - CESifo

$\mathrm{GmbH}$

The international platform of Ludwigs-Maximilians University's Center for Economic Studies and the ifo Institute

Poschingerstr. 5, 81679 Munich, Germany

Telephone +49 (0)89 2180-2740, Telefax+49 (0)89 2180-17845, email office@cesifo.de

Editor: Clemens Fuest

https://www.cesifo.org/en/wp

An electronic version of the paper may be downloaded

- from the SSRN website: www.SSRN.com

- from the RePEc website: $\quad$ www.RePEc.org

- from the CESifo website: https://www.cesifo.org/en/wp 


\title{
Gathering Support for Green Tax Reform: Evidence from German Household Surveys
}

\begin{abstract}
Green tax reform is unpopular because, typically, the poor are hurt most by the higher prices of carbon-intensive commodities. If revenues from a carbon tax are recycled, it may be feasible to gain popular support for green tax reform. To investigate this, we estimate an EASI demand system from German household data and a labour supply schedule, using wage data, and the German income tax schedule and let emission intensities decline in the carbon tax. If the revenue from a carbon tax is recycled via a lump-sum transfer to all households, this gives more equitable albeit less efficient outcomes, yet $70 \%$ of households are worse off. If the revenue is recycled via lower income taxes, there is more efficiency at the expense of more inequality, and about half of households benefit. With a recycling mix of lump-sum transfers and lower income taxes, popular support can be mustered without hurting equity too much. We also investigate the effects of Germany meeting its legal target for curbing emissions by 55\% in 2030 relative to 1990 levels. We find that most of emission reductions are due to producers responding by lowering emission intensities rather than by consumers to less carbon-intensive consumption categories.
\end{abstract}

JEL-Codes: D120, D310, D620, D630, H230, J220, Q500.

Keywords: popular support, carbon tax, revenue recycling, equity, EASI demand system, labour supply.

\author{
Frederick van der Ploeg \\ Department of Economics \\ University of Oxford \\ United Kingdom - Oxford OX1 3UQ \\ rick.vanderploeg@economics.ox.ac.uk
}

Armon Rezai

Department of Socio-Economics

University of Economics and Business

Austria - 1020 Vienna

armon.rezai@wu.ac.at
Miguel Tovar

The Economics and Social Research Institute Ireland - Dublin 2

Miguel.AngelTovar@esri.ie

Revised October 2021

We thank Gilbert Metcalf, Terry Iverson, Colleen Schneider, Arthur Schweitzer and the participants of the ifo Workshop on Heterogeneous Agents and the Macroeconomics of Climate Change and at seminars at Colorado State University for helpful suggestions. Tovar Reanos acknowledges funding from the ESRI's Energy Policy Research Centre. 


\section{Introduction}

The European Union and its member states are global leaders in the transition to a carbon-free economy. Policy pledges include a reduction of at least $40 \%$ of greenhouse gas emissions by 2030 relative to 1990 at the European level. Several member states have already committed to near carbon neutrality, i.e. cessation of emissions, by 2050. Despite this ambition, the European Union and many of its member states find it hard to meet their own pledges. They face increasing resistance to the necessary policy measures from parts of their populace who perceive green policies to hurt the poor relatively more than the rich. To overcome this fatigue and distributional stumbling blocks of reform, the European Commission announced a Green Deal which attempts to deal with energy poverty and the sectoral and regional implications of the fundamental structural change to carbon neutrality. ${ }^{1}$ However, wider considerations of the potential distributional impacts of green tax reforms across all households are absent in initial announcements despite a general commitment to a “just transition".

Carbon taxes combat climate change and curb the concentration of fine airborne particles but they tend to be regressive and generate protests. By using the revenue from the carbon tax one can make carbon taxes more equitable. For example, Horowitz et al. (2017) find that $70 \%$ of people in the US are better off if the revenue of taxing greenhouse gases at $\$ 49$ per ton of CO2 equivalent is rebated as a lump-sum transfer of \$583 per person. Klenert et al. (2018) argue that recycling all revenues from the carbon tax as a visible and transparent carbon dividend (a lump-sum transfer) generates enough political support to make green tax reform politically acceptable. $^{2}$

We demonstrate that this argument is not true for Germany where recycling all revenue via transfers leads to an inefficient green transition. Our contribution is to focus on how the revenue recycled from the carbon tax affects the number of households that gain from the green tax reform. The novelties of our analysis are to estimate the Exact Affine Stone Index (EASI) commodity demand system of Lewbel and Pendakur (2009), to capture the nonlinearity of Engel curves and the own and cross price effects, and to calibrate emissions intensities as declining function of carbon prices. We focus on emission taxes and consider only emissions

\footnotetext{
${ }^{1}$ The European Commission increased its pledge to halving emissions by 2030 relative to 1990 and aiming for carbon neutrality by 2050. In 2018, EU wide emissions had fallen by $23 \%$ relative to 1990 .

${ }^{2}$ In the U.S. the Climate Leadership Council found that the carbon tax plus dividend received two to one support among Republican Senators, four to one support overall, and six to one support among Republicans under forty.
} 
of households in Germany, not abroad. We use this framework to analyse the equity and efficiency aspects of various types of green tax reform in Germany.

Our criterion to assess whether households are better off or not is not whether they have more, or less, money in their pocket or purchasing power as result a of the tax-cum-dividend policy. Instead, we look at whether utility of each household goes up or down, suitably allowing for behavioural adjustments in consumer demand and labour supply of each household. A carbon tax in our framework erodes the real consumption wage, curbs labour supply, and thus depresses the labour income tax base. It also induces a shift from carbon-intensive to carbonextensive consumption categories. These effects increase the fiscal cost of climate policy.

To make our case, we use German household data on disaggregated household income, consumption, labour supply, and carbon footprints to investigate empirically the effects of green tax reform proposals. Our labour supply function ignores income effects as we assume that disutility of labour is weakly separable from the utility of the consumption basket. We calculate the equivalent variations (the amounts of consumption each household is willing to sacrifice to ensure that the package of a carbon price - including the way it is recycled - is implemented) to get a monetary measure of how much each household gains from the various types of green tax reform and recycling policy. We use this framework to trace out the effects on the utility of each household for a carbon tax of 50 Euro per ton of emitted $\mathrm{CO}_{2}$, which is fully recycled either as a lump-sum carbon dividend or an across-the-board cut in income taxes or which is not recycled at all. Not recycling at all curbs economic activity, makes most people worse off and offers little hope of getting political support for green tax reform. Recycling all revenue fully as a carbon dividend helps the poor but makes the rich worse off both because of higher consumer prices and because income taxes must rise to balance the budget. Only 30\% of mostly poorer people are better off, but this recycling policy offers no hope of a political majority for green tax reform either. ${ }^{3}$ Recycling all revenue as lower income tax rates boosts labour supply and economic activity but hurts the poor. Still, just more than half of the population is better off and therefore a majority for green tax reform is achieved. If the government cares about equity, we show that it wants to recycle some of the revenue to lower income taxes and some for a carbon dividend.

Recycling all revenue via a carbon dividend increases consumer prices, depresses the real consumption wage, and thus lowers labour supply and the income tax base. We show that this

\footnotetext{
${ }^{3}$ However, if we keep labour supply as exogenous, we find roughly in line with Horowitz et al. (2017) that about $70 \%$ of households are better off if a carbon tax is introduced and revenue is rebated via lump-sum transfers.
} 
means that the income tax rates must rise for the budget to remain balanced, resulting in a further decline in economic activity. It is thus impossible to recycle all carbon tax revenue via a carbon dividend without having to raise labour income tax rates. The proposal to recycle all carbon tax revenue as lump-sum transfers thus does not yield political support and leads to a too costly de-carbonisation of the economy.

We investigate in some detail the effects of the different types of green tax reform on horizontal and vertical equity. If carbon tax revenue is used to hand out a transfer, support is higher under single households. If it used to lower income taxes, support is highest under households with children and under households which are headed by males. While a slim majority of rural households are better off, the measure would only be rejected if single households were to decide. We compare the effects of carbon tax of 50 Euro per ton of $\mathrm{CO}_{2}$ with the effects that occur when the carbon tax must adjust to achieve Germany’s legal target of cutting emissions by $55 \%$ in 2030 relative to 1990 .

Our contribution focuses on Germany, uses commodity demands estimated from the EASI demand system, and displays equivalent variations across households. We therefore allow for very general shapes of Engel curves, which allows us to capture important consequences for green tax reform across heterogeneous households, most importantly its distributional effects. While our findings are broadly akin to those of previous contributions regarding the trade-off between equity and efficiency, we also ask if the proposal would pass a majority vote. Using equivalent variations as criterion to evaluate policy proposals, we find that the majority of households would welcome carbon pricing if its proceeds are used to lower income taxes, whereas only a third would agree to carbon pricing if revenues are recycled via transfers.

Section 2 describes our micro-based model for evaluation of climate policies and recycling revenue and discusses how to calculate the equivalent variations associated with each policy package for each household. Section 3 presents the estimates of our EASI demand system and the labour supply schedule and the calibration of the income tax schedule and the model of emission intensities, where the data that have been used are described in Appendix A. Section 4 presents the effects of different ways of recycling the revenue from a given carbon tax and discusses the effects on equity, efficiency, aggregate emissions, and the degree of popular support. It also examines the effects of different recycling schemes when the carbon tax adjusts to achieve the stated target of a 55\% cut in aggregate emissions relative to 1990 . The solution 
techniques used to perform our policy simulations are discussed in Appendix C. ${ }^{4}$ Section 5 discusses our results in a broader context. Section 6 concludes.

\section{Methods: A micro-based model for climate policy evaluation}

In section 2.1 we discuss the system for commodity demands. We then discuss in section 2.2 income taxes and labour supply, and in section 2.3 emissions intensities and how they depend on the carbon tax as well as aggregate emissions, and in section 2.4 the government budget constraint. Finally, we discuss in section 2.5 our policy experiments and how we measure their effects on utility of households as measured by equivalent variations.

\subsection{The EASI commodity demand system}

Our sample consists of $H$ households and the population weight for household $h$ is $N_{h}$. Each household consumes I commodities. Indirect utility of the commodity bundle consumed and total expenditure on commodities by household $h$ are denoted by $v_{h}$, and $y_{h}$, respectively. We denote the consumer price of commodity $i$ including carbon taxes to household $h$ by $q_{h i}$ and denote the corresponding I-dimensional vector of consumer prices for household $h$ by $\vec{q}_{h}$. The indirect utility function $v_{h}=v_{h}\left(\vec{q}_{h}, y_{h}\right)$ depends on consumer prices and total expenditure by household $h$ denoted by $y_{h}$. With constant marginal utility of income, Marshallian consumption demands are $\vec{x}_{h}\left(\vec{q}_{h}, y_{h}\right)=\partial v_{h}\left(\vec{q}_{h}, y_{h}\right) / \partial \vec{q}_{h}$. The expenditure function for household $h$ depends this price vector and indirect utility, and will be written as $X\left(\vec{q}_{h}, v_{h}\right)$. Application of Shephard's lemma gives the optimal Hicksian demands and budget shares. For the Exact Affine Stone Index (EASI) demand system put forward by Lewbel and Pendakur (2009), the budget shares are

$$
w_{h i}=\sum_{r=0}^{R} b_{i r} \log \left(v_{h}\right)^{r}+\sum_{j=1}^{I} a_{i j} \log \left(q_{h i}\right)+\sum_{k=1}^{K}\left[d_{i k} z_{h k} \log \left(v_{h}\right)+g_{i k} z_{h k}\right] \text {, }
$$

where $w_{h i} \equiv q_{h i} x_{h i} / y_{h}$ and $z_{h k}$ are the budget share of commodity $i$ and the household characteristic $k$ for household $h$, respectively. The right-hand side includes a sum of various powers of the log of indirect utility, where $R$ is determined by the statistical significance of the associated coefficients. The number of household characteristics are $K$. The budget share

\footnotetext{
${ }^{4}$ The computer code for estimation and policy simulations is available upon request.
} 
equations are homogenous of degree zero in prices, so that only $I-1$ budget shares need to be estimated. The log of indirect utility of household $h$ is derived in Lewbel and Pendakur (2009) and depends on total expenditure of household $h, y_{h}$, and the budget shares and prices of all the $I$ commodities,

$$
\log \left(v_{h}\right)=\log \left(y_{h}\right)-\sum_{j=1}^{I} w_{h j} \log \left(q_{h j}\right)+\frac{1}{2} \sum_{i=1}^{I} \sum_{j=1}^{I} a_{i j} \log \left(q_{h i}\right) \log \left(q_{h j}\right)
$$

where the $a_{i j}$ are the estimated compensated price effects in commodity demand (1). Upon substitution of (2) into (1), we obtain an indirect system for the budget shares

$$
\begin{aligned}
w_{h i}=b_{i 0} & +\sum_{r=1}^{R} b_{i r}\left[\log \left(y_{h}\right)-\sum_{j=1}^{I} w_{h j} \log \left(q_{h j}\right)+\frac{1}{2} \sum_{j=1}^{I} \sum_{j^{\prime}=1}^{I} a_{j j^{\prime}} \log \left(q_{h j}\right) \log \left(q_{h j^{\prime}}\right)\right]^{r}+\sum_{j=1}^{I} a_{i j} \log \left(q_{h i} / q_{h j}\right) \\
& +\sum_{k=1}^{K} d_{i k} z_{h k}\left[\log \left(y_{h}\right)-\sum_{j=1}^{I} w_{h j} \log \left(q_{h j}\right)+\frac{1}{2} \sum_{j=1}^{I} \sum_{j^{\prime}=1}^{I} a_{j j^{\prime}} \log \left(q_{h j}\right) \log \left(q_{h j^{\prime}}\right)\right]+\sum_{k=1}^{K} g_{i k} z_{h k} .
\end{aligned}
$$

We can solve (1') for the budget shares as functions of total expenditure $y_{h}$ and consumer prices $q_{h j}$ (and of household attributes and the estimated coefficients of the EASI system).

The EASI demand system (1)-(2) is very flexible and allows for non-homothetic preferences and nonlinear Engel curves with underlying preferences that are not of the Gorman polar form. The budget shares in (1') depend on various powers of the log of total consumer expenditure and consumer prices. Engel curves need thus not be linear but can be concave or convex and can slope down or upwards. Budget shares add up to one, $\sum_{i=0}^{I} w_{h i}=1$. These constraints and Slutsky symmetry imply the following restrictions on the parameters to be estimated

$$
\begin{gathered}
\sum_{i=1}^{I} b_{i 0}=1, \quad \sum_{i=1}^{I} \sum_{k=1}^{K} g_{i k}=0, \quad \sum_{i=1}^{I} \sum_{k=1}^{K} d_{i k}=0, \quad \sum_{i=1}^{I} \sum_{r=1}^{R} b_{i r}=0, \\
a_{i j}=a_{j i}, i, j=1, . ., I \text { and } \sum_{j=1}^{I} a_{i j}=0, \quad i=1, . ., I .
\end{gathered}
$$

We estimate the system for $I-1$ of the commodities and imposing only the $I(I-1) / 2$ symmetry conditions. Demand for commodity $I$ follows residually because budget shares add up to one. The unit-expenditure function or ideal cost-of-living index follows from (2) and is given by

$$
P_{h}^{A} \equiv \frac{y_{h}}{v_{h}}=\left(\prod_{i=1}^{I} q_{h i}^{w_{h i}}\right) e^{-\frac{1}{2} \sum_{i=1}^{I} \sum_{j=1}^{I} a_{i j} \log \left(q_{h i}\right) \log \left(q_{h j}\right)} .
$$


If all the $a_{i j}$ are zero and budget shares are constant, we have Cobb-Douglas preferences with $y_{h} / v_{h}=\prod_{i=1}^{I} q_{h i}^{w_{h i}}$. In general, the index (4) is implicitly defined due to the presence of the $w_{h i}$ which need to be substituted in from (1) or (1').

From equation (1) we get $\frac{\partial w_{h i}}{\partial y_{h}}=\left[\sum_{r=1}^{R} b_{i r} r \log \left(v_{h}\right)^{r-1}+\sum_{k=1}^{K} d_{i k} z_{h k}\right] \frac{d \log \left(v_{h}\right)}{d y_{h}}$ and from (2) we get $\frac{d \log \left(v_{h}\right)}{d y_{h}}=\frac{1}{y_{h}}-\sum_{j=1}^{I} \log \left(q_{h j}\right) \frac{\partial w_{h j}}{\partial y_{h}}=\frac{1}{y_{h}}-\left(\sum_{j=1}^{I} \log \left(q_{h j}\right)\left[\sum_{r=1}^{R} b_{j r} r \log \left(v_{h}\right)^{r-1}+\sum_{k=1}^{K} d_{j k} z_{h k}\right]\right) \frac{d \log \left(v_{h}\right)}{d y_{h}}$, so that the marginal cost of utility for household $h$ is

$$
P_{h}^{M} \equiv \frac{d y_{h}}{d v_{h}}=\frac{y_{h}}{v_{h}}\left\{1+\sum_{j=1}^{I} \log \left(q_{h j}\right)\left[\sum_{r=1}^{R} b_{j r} r \log \left(v_{h}\right)^{r-1}+\sum_{k=1}^{K} d_{j k} z_{h k}\right]\right\} .
$$

Equation (5) gives the derivative of household expenditure with respect to indirect utility, keeping consumer prices constant but allowing for changes in budget shares. This marginal cost of utility corresponds to the average cost of utility (4) times a correction factor (the term in curly brackets). With Cobb-Douglas preferences the budget shares are constant, so that all coefficients except the $b_{i 0}$ in (1) are zero and the correction factor in curly brackets in (5) equals one. More generally, if all coefficients except the $b_{i 0}, g_{i l}$ and $a_{i j}$ are zero, demand is homothetic and expression (5) becomes $\frac{d y_{h}}{d v_{h}}=\frac{y_{h}}{v_{h}}$ or $P_{h}^{M}=P_{h}^{A}$. In this case, the distribution of income does not affect aggregate demand. In general, however, demand is not homothetic, in which case the correction factor in curly brackets in (5) differs from 1 and the marginal cost of utility no longer equals the average cost of living for each household.

\subsection{Income taxes and labour supply}

Household $h$ supplies $l_{h}$ units of labour and receives a gross wage $W_{h}$ and a uniform lump-sum transfer $s$ from the government. It may also receive other exogenous income $\bar{y}_{h}$. It is subject to a nonlinear income tax schedule of the form $T_{h}=T_{h}\left(W_{h} l_{h}+\bar{y}_{h}\right)$, where the marginal tax rate is denoted by $t_{h}^{M} \equiv \partial T_{h}\left(W_{h} l_{h}+\bar{y}_{h}\right) / \partial\left(W_{h} l_{h}+\bar{y}_{h}\right)$. The income tax system is progressive if the marginal tax rate exceeds the average tax rate $t_{h}^{A} \equiv T_{h}\left(W_{h} l_{h}+\bar{y}_{h}\right) /\left(W_{h} l_{h}+\bar{y}_{h}\right)$. The measure of residual income progression (RIP) is defined by $0<\left(1-t_{h}^{M}\right) /\left(1-t_{h}^{A}\right)<1$. It shows by what percentage net income of a household of type $h$ increases if its gross income increases by $1 \%$, 
hence the more the RIP falls short of 1 the more progressive the income tax system. The nonlinear income tax schedule $T_{h}($.$) is a smooth function of gross income. In practice, it often$ is a piece-wise linear or linear-quadratic schedule. We denote total spending on consumption goods and exogenous saving of household $h$ by $y_{h}$ and $\sigma_{h}$, respectively, so that the budget constraint for household $h$ is

$$
y_{h}+\sigma_{h}+T\left(W_{h} l_{h}+\bar{y}_{h}\right)=W_{h} l_{h}+\bar{y}_{h}+s \varsigma_{h} .
$$

where $s$ denotes the tax-free normalised carbon dividend with $\varsigma_{h}$ a correction factor for the size of the household (depending on the number of adults and children). Let total utility of household $h$ be indirect utility from the bundle of consumption goods minus disutility of work minus disutility of aggregate pollution, so that it is of the separable form

$$
u_{h}=v_{h}\left(\vec{q}_{h}, y_{h}\right)-\phi_{h} \frac{l_{h}^{1+1 / \varepsilon^{F}}}{1+1 / \varepsilon^{F}}-\psi_{h} E, \quad \phi_{h}>0, \quad \varepsilon^{F}>0, \quad \psi_{h} \geq 0
$$

where $\varepsilon^{F}$ is the Frischian wage elasticity of labour supply, $\phi_{h}$ is the disutility of labour cost parameter (in Euro per disutility of work), $\psi_{h}$ is the disutility cost of pollution for household $h$ (in Euro per aggregate pollution), and $E$ denotes aggregate emissions. The disutility of aggregate emissions might differ across households if, for example, lower income households suffer more from emissions than higher income households. The three terms in the utility function are all measured in Euro per quarter.

Households take taxes and transfers and aggregate emissions as exogenous. Maximising (7) subject to (6) thus gives labour supply for household $h$ as

$$
l_{h}=\left(\frac{1}{\phi_{h}} \frac{\left(1-t_{h}\right) W_{h}}{P_{h}^{M}}\right)^{\varepsilon^{F}},
$$

where $P_{h}^{M} \equiv d y_{h} / d v_{h}$ denotes the marginal cost of utility for household $h$. Expression (8) indicates that labour supply rises in the after-tax wage and decreases in the marginal cost of utility. Due to the quasi-linear nature of the utility function (7) there are no income effects in labour supply. A specific tax on carbon emissions, $\pi>0$, increases consumer prices and the marginal cost of utility and thus curbs labour supply. If some of the revenue from the carbon tax is used to lower the marginal income tax rate, the fall in labour supply is mitigated. Rebating carbon tax revenue via lump-sum transfers has no additional effects on labour supply. 


\subsection{Emission intensities and aggregate emissions}

Each household responds to carbon prices by, on the one hand, changing the composition of demand towards less carbon-intensive commodities, and, on the other hand, by reducing labour supply, commodity demand and emissions. Government policy can further redistribute income away from high-emission households to those with a low carbon footprint. However, these effects may be small compared to technological change in the production of commodities. We therefore also permit supply-side responses of firms, so that higher carbon taxes induce firms to adjust production towards lower emission intensities to cut costs.

We link carbon intensities to a backstop technology, which is available at fixed price across all sectors. Firms can lower consumer prices by lowering the emissions intensity of their products in response to a carbon price, and thus increase the demand for their products. In equilibrium, the cost of internally avoiding an extra ton of carbon for firms must equal the carbon price. We adopt the abatement cost function of the DICE-2016R model (Nordhaus, 2017), so that the cost of curbing emissions is $R(\rho)=\beta \rho^{1+\varepsilon} /(1+\varepsilon)$ with $\beta$ the backstop price and $\varepsilon$ the price elasticity of emissions reduction $\rho$. In equilibrium, the marginal cost of curbing emissions must equal the carbon price, $R^{\prime}(\rho)=\pi$, so $\rho=(\pi / \beta)^{\varepsilon}$. With the remaining carbon content of consumer goods equal to $1-\rho$, consumer prices including carbon taxes are given by

$$
\vec{q}_{h}=\vec{p}_{h}+\pi(1-\rho) \vec{e}_{h} \text { with } \rho=(\pi / \beta)^{\varepsilon},
$$

where consumer prices before carbon taxes $\vec{p}$ are exogenous. The vector $\vec{e}_{h}$ denotes unabated emissions per quantity consumed of each commodity by household $h$. The emissions intensities differ across households as their consumption baskets differ. Aggregate emissions are

$$
E=\sum_{h=1}^{H} N_{h}(1-\rho) \vec{e}_{h}{ }^{\prime} \vec{x}_{h}\left(\vec{q}_{h}, y_{h}\right)
$$

\subsection{The government budget constraint}

The government can use lump-sum transfers $s$, across-the-board income tax cut $\lambda$, and the specific carbon tax $\pi$ as instruments. The government has an exogenous revenue requirement to finance spending and reductions in borrowing. Revenues from the income tax and carbon tax must cover the exogenous public revenue requirement, $M$, and total lump-sum transfers,

$$
(1-\lambda) \sum_{h=1}^{H} N_{h} T_{h}\left(W_{h} l_{h}+\bar{y}_{h}\right)+\pi E=M+\sum_{h=1}^{H} N_{h} \varsigma_{h} S,
$$


where $\lambda$ indicates the across-the-board reduction in income taxes. For simplicity, we assume that public revenue requirement, $M$, solely funds ineffective public goods and, therefore, does not enter the household utility function (7).

\subsection{Policy experiments and their effects on households}

We are interested in two types of policy experiments. The first one is to introduce or increase a carbon tax where the revenue is not recycled or used to either hand out a lump-sum transfer to all households or cut income taxes across the board (see section 4.1). The second one is to meet a pre-specified target for emissions reductions where the carbon tax adjusts to ensure that the target is met, where we compare again the case of no recycling of carbon tax revenue with the two models of recycling (see section 4.2).

For each policy experiment we want to know what the effects on efficiency and equity are. We also want to know whether, in line with the double dividend literature, recycling via the lower income tax leads to a contraction or boost in employment, and on what factors the answer might depend. We also want to know what the effect of each policy experiment on utility is for each type of household. For this purpose, we calculate for each type of household the equivalent variation of a policy change, i.e. the amount of consumption this type of household is willing to sacrifice to see a policy package implemented. For each household $h$ we can calculate its overall utility as a function of the policy package, $\Theta_{m}$, say $u_{h}=U_{h}\left(\Theta_{m}\right)$, where $m$ corresponds to either (i) $m=1$ for the carbon tax without recycling policy (higher $M$ ), or (ii) $m=2$ for the carbon tax cum dividend policy (higher s), or (iii) $m=3$ for the carbon tax plus income tax reduction policy (lower $\lambda$ ). Once the parameters from the demand system and labour supply are estimated, the effect on overall utility of household $h$ measured in Euro for each of the three policies is calculated as $U_{h}(\Theta)-U_{h}\left(\Theta_{0}\right)$, where $\Theta_{0}$ indicates the baseline policies. Including policy package $m$ as an argument in the expenditure function, say $X_{h}\left(\vec{p}_{h}, v_{h} ; \Theta_{m}\right)$ for household $h$, the equivalent variation equals

$$
\begin{gathered}
X_{h}\left(\vec{p}_{h}, v_{h}\left(\Theta_{m}\right) ; \Theta_{m}\right)-X_{h}\left(\vec{p}_{h}, v_{h}\left(\Theta_{0}\right) ; \Theta_{0}\right)=\exp \left[\ln \left(y_{h}^{m}\right)+\sum_{i=1}^{I}\left(w_{h i}^{0} \ln \left(p_{h i}^{0}\right)-w_{h i}^{m} \ln \left(q_{h i}^{m}\right)\right)\right] \times \\
\exp \left[\frac{1}{2} \sum_{i=1}^{I} \sum_{j=1}^{I} a_{i j} \ln \left(q_{h i}^{m}\right) \ln \left(q_{h j}^{m}\right)-\frac{1}{2} \sum_{i=1}^{I} \sum_{j=1}^{I} a_{i j} \ln \left(p_{h i}^{0}\right) \ln \left(p_{h j}^{0}\right)\right]-y_{h}^{0},
\end{gathered}
$$

where $m=1,2,3$, indicates the three policy scenarios and the superscript 0 denotes the base scenario of no change in climate policy. This equivalent variation is measured in Euro and, if 
negative, it corresponds to the amount household $h$ is prepared to pay to avoid the policy package. We will report these figures for all households to gain insights into the distributional impacts of the three policy packages rather than aggregating everything into one social welfare function. This allows us to investigate what kind of green reforms can count on popular support.

\section{Empirical Results}

In sections 3.1 and 3.2 we discuss our estimates of the EASI demand system for commodity demands and labour supply, respectively. Our calibration of the German income tax system is presented in section 3.3. In section 3.4 we discuss the carbon footprints and our calibration of how producers reduce their emissions intensity in response to a carbon tax.

\subsection{Estimation of EASI demand system}

While demand systems have been estimated many times before, their use in computing optimal taxes to internalise externalities of consumption of polluting commodities is rare. West and Williams (2007) use the Almost Ideal Demand System (AIDS) for which Engel curves are linear in log of total expenditure (Deaton and Muellbauer, 1980). The quadratic AIDS demand system model has Engel curves that are quadratic in log of total expenditure (Banks et al., 1997). The shape of the estimated Engel curve is an important driver of the optimal corrective and income taxes and their distributional consequences (Jacobs and van der Ploeg, 2019). The Exact Affine Stone Index (EASI) implicit Marshallian demand system proposed by Lewbel and Pendakur (2009) is a flexible model that allows for general forms of Engel curves. It has been applied to estimate German household demand by Tovar and Wölfing (2018). We deploy the EASI model because of its unique characteristics regarding flexibility, theoretical consistency and because its error terms can be interpreted as random utility parameters representing unobserved heterogeneity across households. This permits us to fully explain observed consumption patterns in the base scenario.

We analyse $I=8$ commodity types: food, housing, electricity heating, transportation, services, durables, and others. The category heating includes gas and liquid and solid fuels used for residential heating. Our durable category includes expenditure on small appliances, clothing, and shoes, transportation includes expenditure on private and public transportation and services includes expenditure on education and health. This aggregation guarantees positive demand, avoiding corner solutions due to plausible zero expenditure observations which could significantly reduce our sample size. 
Figure 1: Engel curves for the consumption of different commodities
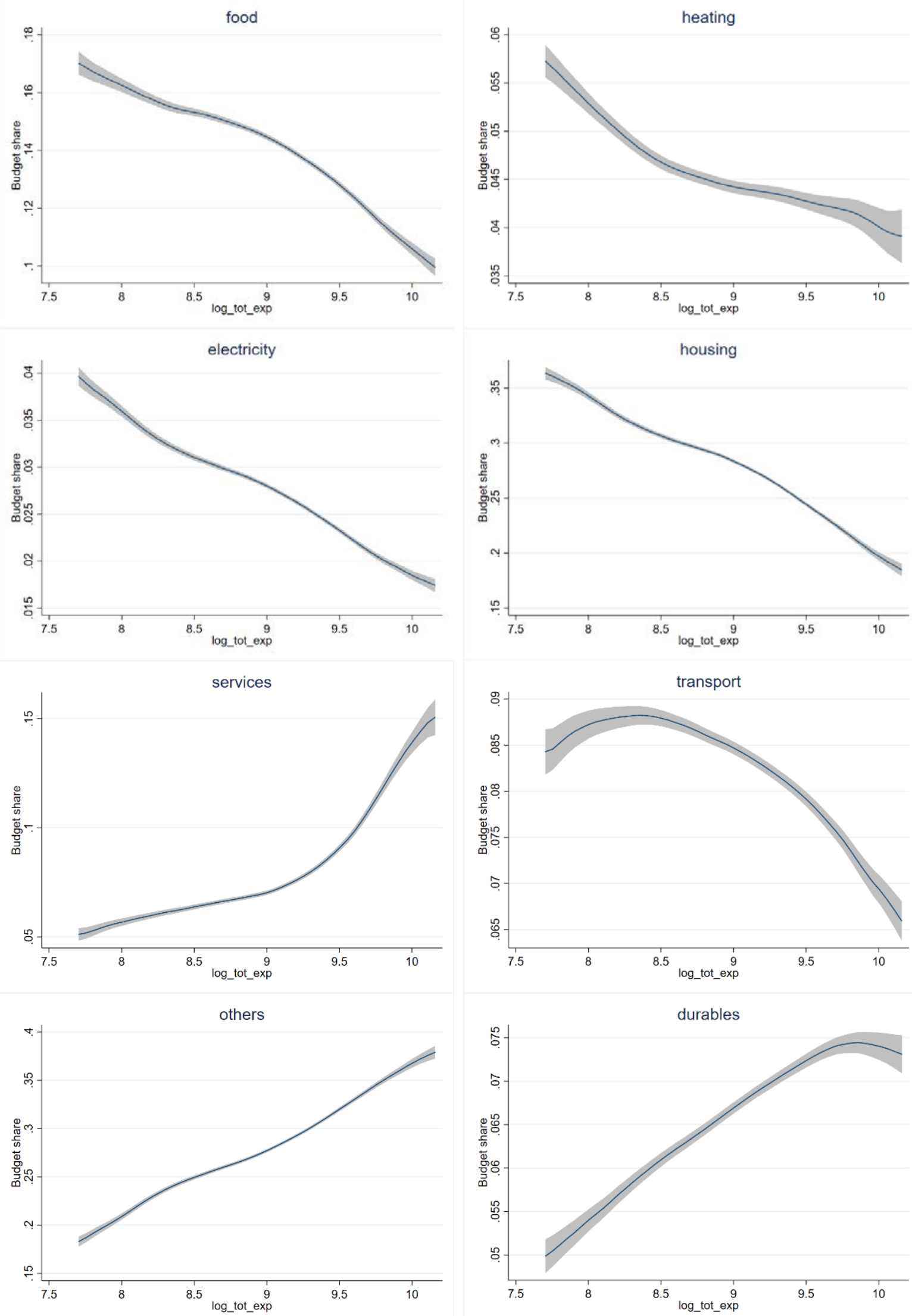
Figure 1 shows, using German data, that Engel curves for different commodities are a combination of linear, quadratic, and higher order polynomials. Budget shares of some commodities rise, others decline, and yet others first rise and then fall with the logarithm of total expenditure. The shapes also indicate that these Engel curves (e.g. heating, transport and services) can be fairly non-linear. Consequently, traditional demand systems with less flexible forms of Engel curves may lead to misleading policy conclusions. Figure 1 also indicates that low-income households spend a larger proportion of their income on heating and electricity than more affluent households, hence carbon taxes on these commodities will be regressive.

To obtain the EASI demand system, we must estimate the parameters: $b_{i r}, a_{i j}, d_{i k}$ and $g_{i k}$ from equation (1). The model requires information on household budget shares, commodity prices and other socioeconomic information. We use the waves 1993, 1998, 2003, 2008 and 2013 of the German survey of incomes and expenditure (EVS) for the econometric estimation. This gives 121,280 observations. For our policy simulations, we use the observations of the 2013 wave. We limit our analysis to 2013 because emissions factors are not available after 2013. For the commodity prices, we use the methodology of Lewbel (1989) to obtain household-specific prices by combining the micro data with the prices reported by the German Statistical Office. This procedure takes advantage of intra-group consumption and exploits household heterogeneity to further improve the identification of price responses. Table A.1 in Appendix A gives a description of the budget shares and commodity prices used in the estimation. We also distinguish $K=8$ types of households in our estimation, i.e. other households, single with age 65+ and no children, single with no children, single with children, two adults 65+ with no children, two adults with no children, two adults with one child, two adults with two children. Table A.2 provides a summary of the distribution of these household types in our sample. The intercept of the demand system depends on several socioeconomic and dwelling characteristics. For the term $g_{i k} z_{h k}$, we use 8 dummies to identify dwelling characteristic, i.e. central heating, district heating, dwelling built before 1948, dwelling built between 1949 and 1990, size of the dwelling, whether a community has less than 20K or between $20 \mathrm{~K}$ and $100 \mathrm{~K}$ habitants, and whether the head of the household is a male subject. We also include dummies for the years 1993, 1998, 2003, 2008 and 2013 that cover the different periods where the applied data is collected.

We follow Lewbel and Pendakur (2009) and use the iterated 3SLS estimator, which is less computationally demanding to estimate than the non-linear GMM estimator. Since this method does not take account of heteroscedasticity in the error terms, we compute standard errors using 
the non-parametric bootstrap method. We use a Monte Carlo estimation routine and follow Tovar and Wölfing (2018) in our econometric specification. ${ }^{5}$ Table A.3 in Appendix A gives the coefficients of the estimated EASI demand system. The first rows in this table display the coefficients from the symmetric Slutsky matrix with elements $a_{i j}$ for the 8 groups of the analysed commodities (food, housing, electricity heating, transport, services, durables, and others). Most of the estimated coefficients are statistically significant. The second block of results in Table A3 corresponds to the coefficients related to the polynomials of indirect utility of the EASI demand system (1) and (2). They are statistically significant and capture the nonlinear shapes of the Engel curves well. The linear or quadratic Engel curves used in earlier empirical studies are thus rejected by the patterns found in our data. The polynomial in the logarithm of indirect utility in equation (1) for the budget shares is of $4^{\text {th }}$ order, $R=4 .^{6}$ Coefficients of higher degree are numerically small and typically statistically insignificant. Our empirical findings substantiate the use of an EASI demand system. The last block of table A3 provides the coefficients of the interaction between the socioeconomic variables and the household indirect utility (i.e. $\left.d_{i k}\right){ }^{7}$

The parameters from the estimated demand system can be used to compute own price and expenditure elasticities ${ }^{8}$ which are given in Tables A.4-A.6. These elasticities are in line with earlier studies using the same data (Tovar and Wölfing, 2018; Pothen and Tovar, 2018; Nikodinoska and Schröder, 2016). We present estimates for the first and fourth expenditure quartiles. The estimates of the own price elasticities for the poorest households are slightly larger. Our estimates suggest that most of our commodities have inelastic demands. Consequently, increases in the price of these commodities could impose a disproportional burden on low-income households who already devote a larger proportion of their income for the purchase of these commodities (see Figure 1). Table A.6 shows that the estimated elasticities with respect to total expenditures are typically lower than one, which indicates that most commodities are necessities. The combination of low own price and income elasticities increases the burden of carbon taxes on low-income households, especially for food, housing, electricity, heating, and transportation.

\footnotetext{
${ }^{5}$ See Horowitz (2001) for technical details of the implementation. See also West and Williams (2007).

${ }^{6}$ Previous models only allow for the introduction of a polynomial of maximum order of 2.

${ }^{7}$ Intercepts related to socioeconomic, time and dwelling characteristics are available upon request.

${ }^{8}$ See Appendix A for the expressions used to compute these metrics.
} 
Note that the estimated coefficients from the demand system can be used to compute the indirect utility function (i.e. equation (2)). These metrics will be used to compute the embedded expenditure function and equivalent variation metrics in our policy simulations.

\subsection{Estimate of labour supply}

Estimates of household labour supply have been used regularly to simulate changes in social welfare after tax reforms (e.g. LaLumia 2008; Cremer et al. 2016; Fadlon and Nielsen, 2019). We follow this approach as our data on expenditure is similarly provided at the household level and Germany applies joint taxation of couples' incomes. Table A.1 gives summary statistics for labour supply. Average worked hours in this table are weekly hours provided by the household, which includes single working households, couples with only one worker, and working couples. ${ }^{9}$ For the estimation, we used the years 2003, 2008 and 2013 of the EVS data because only for these years did the EVS consistently report information on working hours. The mean weekly hours provided by the household in our sample are 50 hours, hence on average households provide 10 working hours per day given a five-day working week. We follow West and Williams (2007) and use the mean of wages across different socio-economic categories as an instrumental variable. We then use GMM to estimate a log-linearised version of the labour supply schedule

$$
\log l_{h}=\alpha_{0}+\alpha_{1} \log \left(\frac{\left(1-t_{h}\right) W_{h}}{P_{h}^{M}}\right)
$$

where the estimated coefficients can be unscrambled from $\phi_{h}=\mathrm{e}^{-\alpha_{0} / \alpha_{1}}$ and $\varepsilon^{F}=\alpha_{1}$. Table A.1 gives summary statistics and Table A.7 of Appendix A gives our econometric estimate of labour supply. This gives a Frischian wage elasticity of $\varepsilon^{F}=\alpha_{1}=0.648$. Note that in our regression $\alpha_{0}$ is estimated for different household types. We also include in $\alpha_{0}$, the coefficient of the inverse Mills ratio evaluated at the mean sample as we follow Heckman (1979) to correct for associated selectivity bias. The socioeconomic variables included in the regression show that rural households supply more working hours. The estimation results also show that households with a male head of the household and one-member households work fewer hours. In our sample couples provide on average 54 hours per week while single households provide 36 hours per week. In addition, couples with a male head of household provide 54 hours on average and couples with a female head provide 55 working hours.

\footnotetext{
${ }^{9}$ Labour supply for pensioners and students is set to zero.
} 
Our estimated disutility of labour $\phi_{h}=\mathrm{e}^{\phi_{0}+\sum d_{h, i} \phi_{i}}$, with $\phi_{0}=-11.40$, $\phi_{\text {rural }}=-0.0633$, $\phi_{\text {male }}=0.044, \phi_{\text {child }}=0.0045, \phi_{\text {single }}=0.699$ (from Table A.7) and $d_{h, i}$ dummy variables for household $h$ and characteristic $i$. The disutility ranges from $€ 1 \times 10^{-5}$ and $€ 2.3 \times 10^{-5}$ per weekly worked hours. ${ }^{10}$

Labour supply in the EVS survey we use is provided on a weekly basis and is aggregated to an annual basis using sample population weights. In our policy simulations we use a random sample of 1000 units from the 2013 wave. The weights in the subsample are scaled to provide the aggregated values of the full EVS sample. Labour disutility is also aggregated to an annual basis using the sample population weights. Across all our policy simulations aggregate disutility of labour varies slightly around $0.7 \%$ of consumption utility.

\subsection{Calibration of the income tax schedule}

We take income brackets and the corresponding marginal tax rates from the German tax system. Taxable income is estimated using all income and the deductions reported in the EVS data. Figure 2 gives the average and marginal tax rates for the German income tax system and our smooth approximations. The marginal tax rate rises from zero to $42 \%$ and the average tax rate rises over this range from zero to $38 \%$ at $€ 150,000$ annual income. Panel (a) plots the marginal tax rates for Germany, which are piecewise linear in income, once positive. ${ }^{11}$ Hence, this continuous approximation (plotted as solid faint lines in Figure 3) provides a good fit. Panel (b) plots the average tax rates implied by the marginal tax rates. The German tax code permits couples to aggregate and split in half their taxable income, resulting in a lower tax bill given the convexity of the tax schedule.

Formally, we approximate the average tax rate by the smooth function $t_{h}^{A}=\max \left(0,-1.47558+0.16353 \ln \left(y_{h}^{A}\right)-\frac{0.70917}{1000000} y_{h}^{A}\right)$ where $y_{h}^{A} \equiv 4\left(W_{h} l_{h}+\bar{y}_{h}\right)-\delta_{h}$ defines annual income minus tax deductibles $\delta_{\text {h }}$. Approximations are plotted in grey in Figure 2. The approximation for average tax rates is very good for taxable incomes up to about 150,000 Euro per year (the range we study). Our data set only reports joint family income and we cannot discern who is earning which part of it, so we assume that all couples split their joint income (given that this strictly lowers the overall tax bill). We abstract from other non-linearities

\footnotetext{
${ }^{10}$ Empirical studies find that labour supply in Europe is inelastic (e.g. Bargain et al. 2014). We estimate labour supply at household, not individual level. Earlier estimates for $\phi_{h}$ are unavailable so comparison is infeasible.

${ }^{11}$ In contrast to other countries, Germany does not have discrete jumps in marginal tax rates.
} 
arising from interactions of the tax code. For example, households may suffer from poverty traps, if child allowances and rent or legal subsidies are targeted at low incomes. Smooth tax functions are often used for (optimal) policy purposes in public finance (e.g. Heathcote et al., 2017).

Figure 2: Average and marginal tax rates for singles in Germany

(a) Marginal tax rate

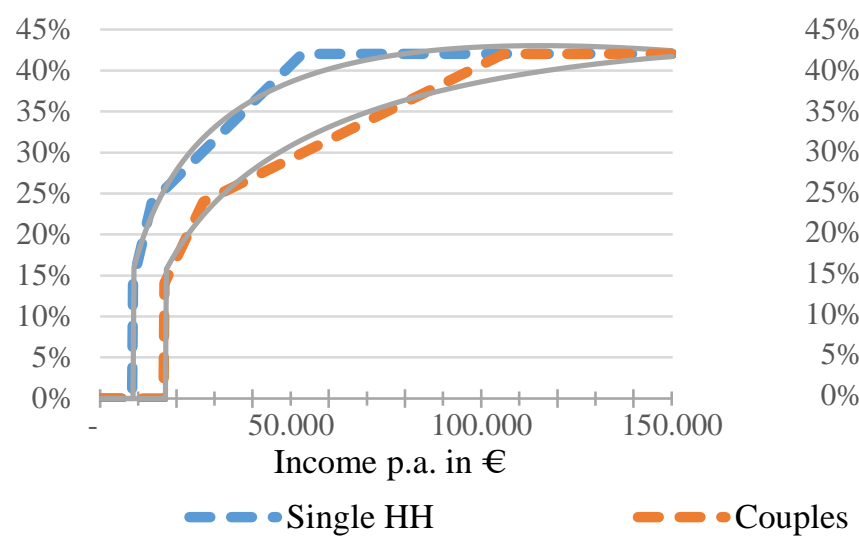

(b) Average tax rate

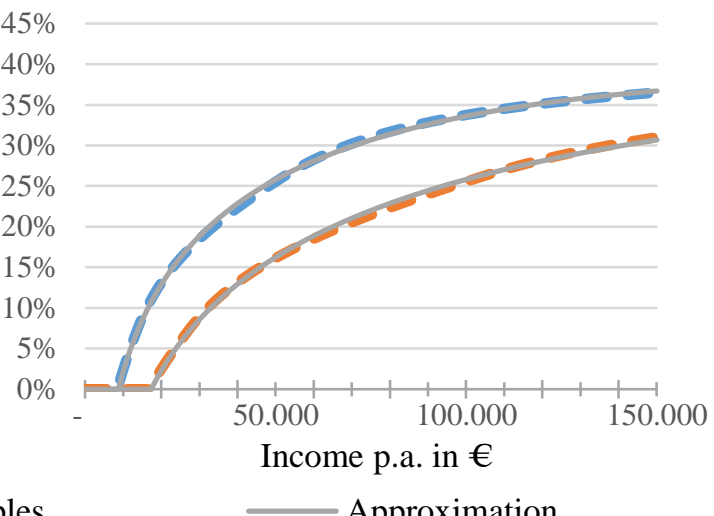
Approximation

\section{Figure 3: Residual income progression (RIP) in Germany}

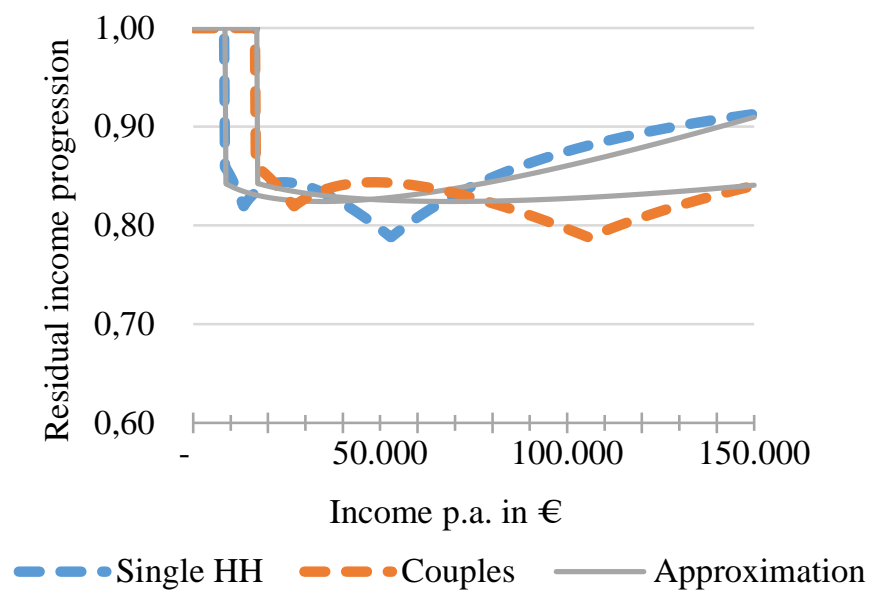

Figure 3 plots the measure of residual income progression, the RIP, which is the elasticity of after-tax labour income with respect to before-tax labour income, or equivalently one minus the marginal tax rate over one minus the average tax rate, $R I P=(1-M T R) /(1-A T R)$. It starts at 1 since the marginal tax within the tax allowance is equal to zero. Once incomes are taxed, the RIP drops to 0.85 , so each $1 \%$ increase in before-tax income yields a $0.85 \%$ increase in after-tax income. The RIP varies between $0.8-0.85$ for most incomes and rises towards 1 for high incomes as the average tax rate approaches the marginal tax rate. 


\subsection{Carbon footprints and endogenous emission intensities}

The German Statistical Office computes $\mathrm{CO}_{2}$ emission content for a highly disaggregated list of consumption commodities using national account data and energy balances. This institution used an input-output model to take account of the interdependences between different sectors of the economy when computed the carbon embedded in different consumption commodities (see Mayer and Flaschmann, 2011). This information is publicly available for the year 2013. The EVS survey follows the COICOP classification for household expenditure. We match carbon footprints with household expenditures from the EVS 2013. We aggregate these metrics for our eight commodities using the German EVS survey data for 2013, which is the latest wave available. ${ }^{12}$ The first panel of Figure 4 displays households' average carbon footprint associated with its consumption by total expenditure quartile. We use equivalence scales for households (e.g. Pollak and Wales, 1981; Lewbel, 1989). The carbon footprints all increase with the expenditure decile. Heating and transport have the highest average emission values. More affluent households thus have a larger carbon footprint. The second panel of Figure 4 gives emission intensities per Euro spent for each of the commodities. These data suggest that transferring one Euro from a poor to a rich household typically decreases emissions.

Figure 4: Emissions and emission intensities due to quarterly consumption

\section{across household distribution}

(a) Emissions ( $\left.\mathrm{kg} \mathrm{CO}_{2}\right)$

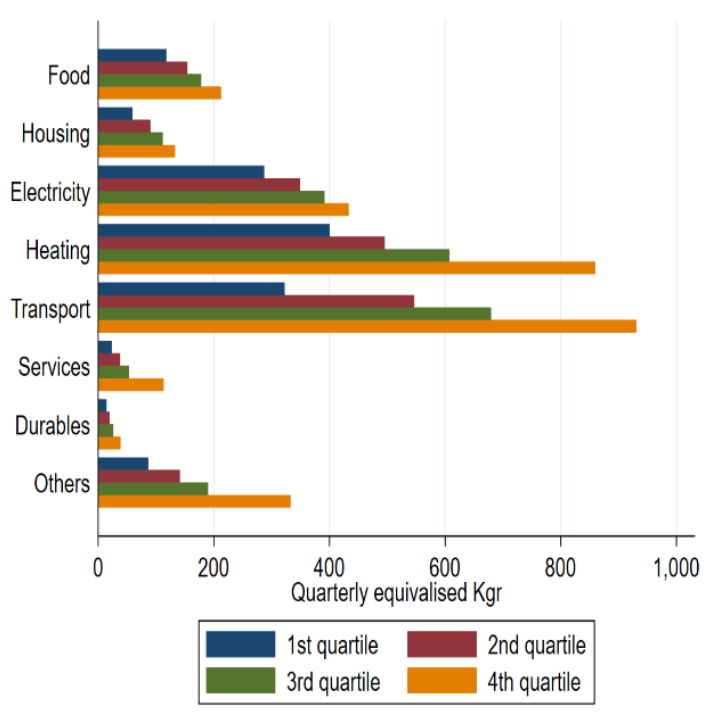

(b) Emission intensities (kg $\left.\mathrm{CO}_{2} / €\right)$

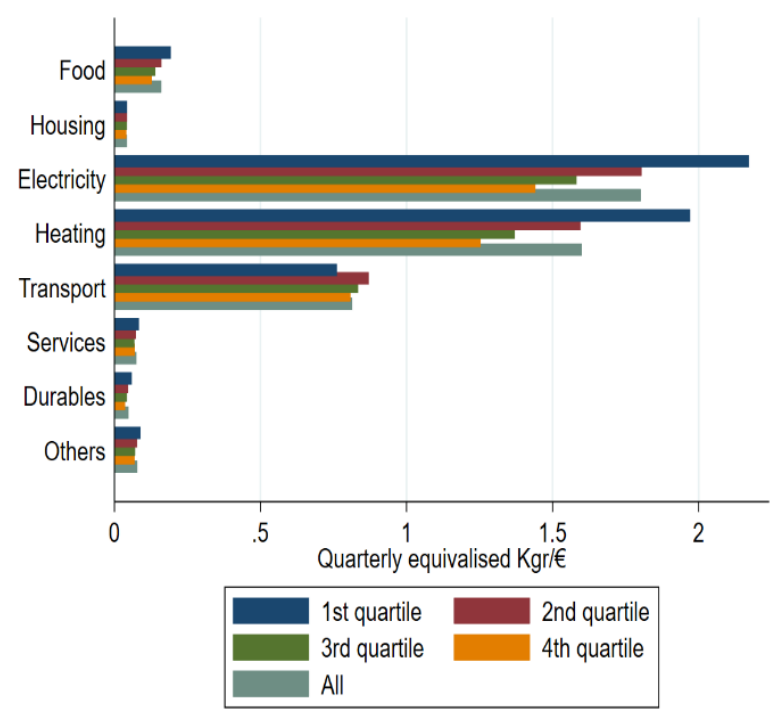

12 'The German Statistical Office provides aggregated data for all consumption categories in the EVS for the year 2013. Details on how we match commodities in the EVS with the carbon content provided by the German Statistical Office are provided in the supporting online material. 
To calibrate the firms' abatement cost function discussed in section 2.3 and the resulting abatement fraction $\rho=(\pi / \beta)^{\varepsilon}$ leading to the endogenous emissions intensity shown in equation (9), we set $\beta$ to $€ 550$ per $\mathrm{tCO}_{2}$ and $\varepsilon$ to $0.625=(2.6-1)^{-1}$. If there is no carbon price, firms do not engage in any mitigation efforts and $\rho=0$. Once the carbon price rises to $€ 550$ per $\mathrm{tCO}_{2}$, it becomes profitable to avoid all emissions or avoid them through carbon capture and storage, i.e. $\rho=1$.

\section{Policy Simulation Results}

This section considers two types of policy experiments. Section 4.1 discusses how the effects of a carbon tax of 50 Euro/ $\mathrm{tCO}_{2}$ on equity, efficiency, emissions, and support depend on whether the carbon tax revenue is not recycled or handed back as lump-sum transfers or an across-the-board cut in income taxes. Section 4.2 shows how the effects of a $55 \%$ cut in emissions relative to the 1990 level, as required by Germany's legal target, on equity, efficiency, the carbon tax, and support are dependent on what is done with the carbon tax revenue.

\subsection{Support for different modes of recycling revenue of a given carbon tax}

Here we analyse what happens if we raise the carbon tax by 50 Euro per ton of emitted $\mathrm{CO}_{2}$ and recycle the revenue via lowering government debt (higher value of $M$ ), paying out a carbon dividend (higher $s$ ), or an income tax reform (lower value of $\lambda$ ). Table 1 summarises the scenario. The numerical solution routine is presented in Appendix C.

Before discussing our policy simulation results, we discuss the baseline, which reflects the current situation in Germany. At the aggregate level, we focus on five key aggregate measures: annual $\mathrm{CO}_{2}$ emissions, annual consumption expenditure, annual hours worked, and the GINI coefficients of gross and net income to gauge income inequality. In the baseline, the sum of $\mathrm{CO}_{2}$ emissions resulting directly and indirectly in the household sector, i.e. the emissions necessary to produce and consume consumption goods, equals $441 \mathrm{MtCO}_{2}$ per year. ${ }^{13}$ This corresponds to aggregate consumption expenditure of 1,141 billion Euro per year. In aggregate

\footnotetext{
${ }^{13}$ We follow a consumption-based approach to carbon emissions but only account for territorial emissions in domestic consumption. Emissions equalled $966 \mathrm{MtCO}_{2}$ in 2015 following environmental-economics accounting conventions, which differs from the $797 \mathrm{MtCO}_{2}$ under the concept used by the IPCC (Destatis, 2019). This figure considers emissions on German territory, including the $579 \mathrm{MtCO}_{2}$ resulting in production of exports. Adding embodied emissions in goods consumed by private households to the sector's direct emissions, total (i.e. direct and indirect) emissions from German households equal $435 \mathrm{MtCO}_{2}$.
} 
households work 60,979 million hours per year. ${ }^{14}$ Table 2 present these key measures for the base line and the three policy scenarios corresponding to a carbon tax of 50 Euro per emitted ton of $\mathrm{CO}_{2}$.

Table 1: Overview of the policy scenarios discussed in sections 5 and 6

\begin{tabular}{|l|c|c|c|}
\hline & $\begin{array}{c}\text { Carbon tax } \\
\pi(€ \text { per tCO }\end{array}$ & $\begin{array}{c}\text { Transfers } \\
s(€ \text { per year) }\end{array}$ & $\begin{array}{c}\text { Tax reduction } \\
1-\lambda(\%)\end{array}$ \\
\hline Baseline & - & - & $0 \%$ \\
\hline Carbon tax of $€ 50 / \mathrm{tCO}_{2}$ & \multicolumn{3}{|c|}{} \\
\hline No recycling & $€ 50$ & - & - \\
\hline Carbon dividend, lump-sum & $€ 50$ & $€ 229$ & - \\
\hline Lowering income taxes & $€ 50$ & - & $8 \%$ \\
\hline 55\% Reduction in $\mathrm{CO}_{2}$ relative to 1990 & $€ 99$ & - & - \\
\hline No recycling & $€ 103$ & $€ 383$ & - \\
\hline Carbon dividend, lump-sum & $€ 113$ & - & $14 \%$ \\
\hline Lowering income taxes & & & \\
\hline
\end{tabular}

Table 2: Aggregates for a carbon tax of 50 Euro/tCO $\mathrm{CO}_{2}$ with different recycling schemes

\begin{tabular}{|c|c|c|c|c|c|c|c|c|}
\hline & \multicolumn{2}{|c|}{$\begin{array}{c}\text { Emissions } \\
\left(\mathrm{MtCO}_{2}\right)\end{array}$} & \multicolumn{2}{|c|}{$\begin{array}{l}\text { Hours worked } \\
\text { (million hours) }\end{array}$} & \multicolumn{2}{|c|}{$\begin{array}{l}\text { Consumption } \\
\text { (billion Euro) }\end{array}$} & $\begin{array}{c}\text { GINI } \\
\text { income }\end{array}$ & $\begin{array}{c}\text { GINI } \\
\text { expenditure }\end{array}$ \\
\hline Baseline & \multicolumn{2}{|c|}{441.8} & \multicolumn{2}{|c|}{60,979} & \multicolumn{2}{|c|}{$€ 1,141 \mathrm{bn}$} & 0.502 & 0.268 \\
\hline \multicolumn{9}{|l|}{ Carbon tax of $€ 50 / t C O 2$} \\
\hline No recycling & 326.06 & $-26 \%$ & 60,546 & $-0.7 \%$ & 1,135 & $-0.5 \%$ & 0.502 & 0.267 \\
\hline Carbon dividend, lump-sum & 329.05 & $-25 \%$ & 60,563 & $-0.7 \%$ & 1,148 & $0.7 \%$ & 0.502 & 0.265 \\
\hline Lowering income taxes & 336.07 & $-24 \%$ & 61,945 & $1.6 \%$ & 1,182 & $3.6 \%$ & 0.505 & 0.274 \\
\hline
\end{tabular}

A carbon tax of $€ 50 / \mathrm{tCO}_{2}$ curbs aggregate emissions by $24-26 \%$ depending on the way the revenue is recycled with supply reductions in emissions intensity contributing $22 \%$ and the demand side the remaining 2-4\%. Aggregate hours worked fall around $0.7 \%$ but rise by $1.6 \%$ if carbon tax revenue is used to cut income taxes. The effect on consumption is ambiguous.

If the additional carbon tax revenue is not returned to households, e.g. used to lower government debt, all households are worse off but emissions in the household sector fall the most, by $26 \%$. This is because households are hit by price rises without being compensated in any form. Hence, utility from consumption and the real wage fall, whereby households prefer to enjoy relatively more leisure, so working time falls by $0.7 \%$. With lower incomes from

\footnotetext{
${ }^{14}$ Our numbers underestimate emissions, consumption expenditure, and hours worked between 15\%-20\%. Given that our findings are based on a sample of 1000 households and that percentage deviations are consistently within the $15-20 \%$, we are confident that differences across simulations contain the relative error and can thus be ignored.
} 
working, consumption expenditure also falls by $0.5 \%$. The reductions in working time and expenditure are modest and similar for all households, so that the impact on distributional measures such as the GINI coefficients for gross income and expenditure are negligible.

Returning the revenue of $€ 50$ per $\mathrm{tCO}_{2}$ to households can fund lump-sum transfers of $€ 229$ per year for a single household (we call this normalised transfer). In accordance with the OECD modified household equivalence scale, households received an additional $50 \%$ of the normalised level for each additional adult and 30\% for each additional child living in the household. The additional income blunts the ability of the carbon tax to lower emissions, which now fall by $25 \%$ (demand-side reduction relative to baseline decreases from $-3.7 \%$ to $-3.0 \%$ ). Consumption expenditure increases by $0.7 \%$ and discourages the provision of labour at the margin. Hours worked fall again by $0.7 \%$. Wage dispersion is hardly affected and the GINI for gross income barely changes. Since lump-sum transfers boost incomes at the bottom relatively more, the distribution of expenditure becomes a little more equal. The GINI in expenditure therefore falls by 0.003 to 0.265 .

The most striking of our policy simulations is the case of a green tax reform where the revenue is used to have an across-the-board reduction in income taxes of $8 \%$. This green tax reform increases the after-tax wage and boosts hours worked, which in the aggregate increase by $1.6 \%$. Larger incomes allow consumption to expand by 3.6\%. Still, carbon emissions are curbed by $24 \%$, albeit with a demand-side reduction less than half the level of the no-recycling case. Given that income taxation in Germany is progressive, a lowering of income taxes by the same amount across all incomes also lowers the progressivity of taxation. The dispersion of gross income increases slightly, but the GINI for expenditure increases significantly to 0.274 corresponding to more inequality.

Our microeconomic policy simulations allow us to look at the distributional implications of our policy experiments at the household level. Figure 5 plots the distribution of the equivalent variations, i.e. the amounts of consumption each household is prepared to pay to see one of the three ways of taxing carbon implemented, across all policy scenarios and households. All panels feature large dispersion across households. Table 3 summarises the distribution and lists the share of different household groups benefitting under each proposal.

Taxing carbon emissions without rebating any revenue lowers welfare for all households. The amount households are willing to pay to avoid this policy ranges between $€ 73$ and $€ 3,365$ per year. The clear negative trend in equivalent variations against income levels is mostly due to 
the positive correlation between income and expenditure levels. If measured as a share of expenditure, this trend in equivalent variations disappears (see Table B.1 in Appendix B).

Figure 5: Impact of climate policy across expenditure, equivalent variations in Euro

(a) Carbon tax of $€ 50 / \mathrm{tCO}_{2}$
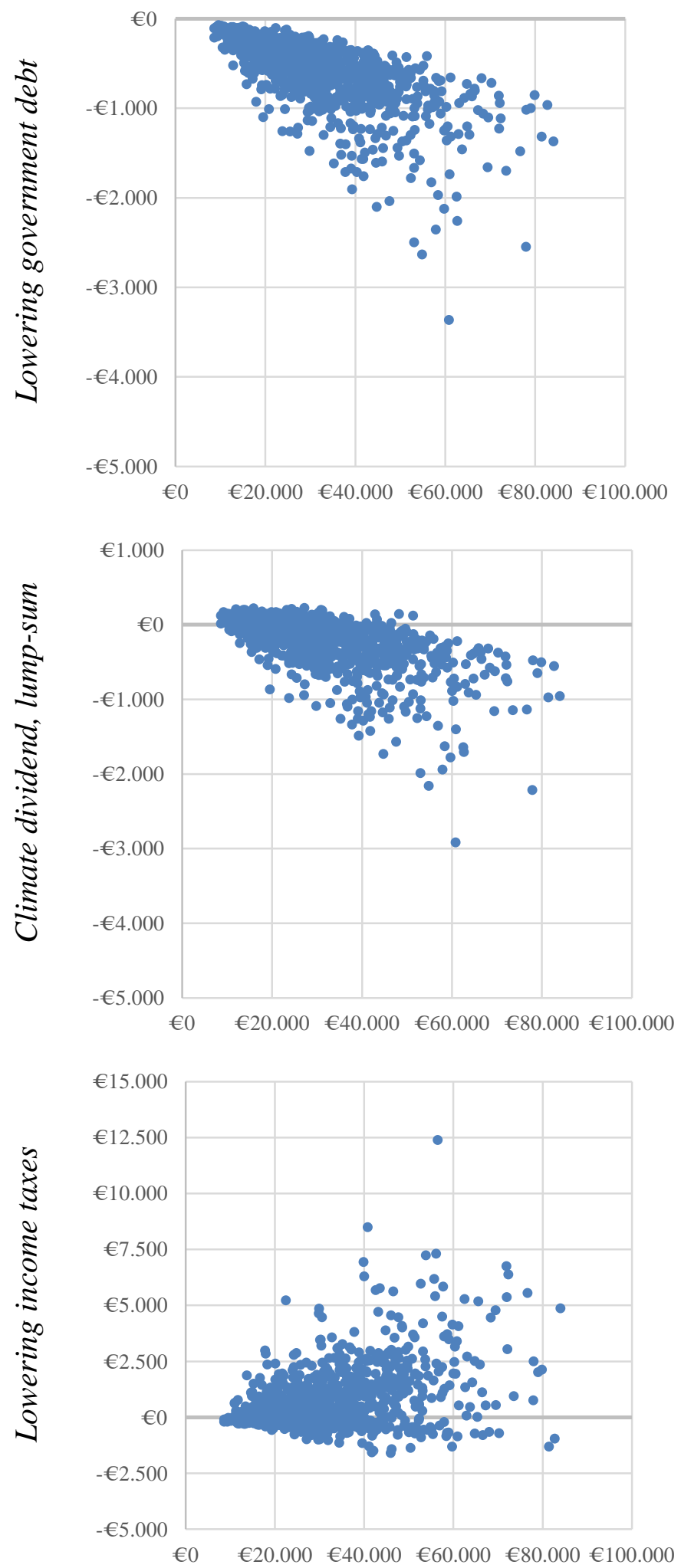

(b) 55\% cut in emissions relative to 1990
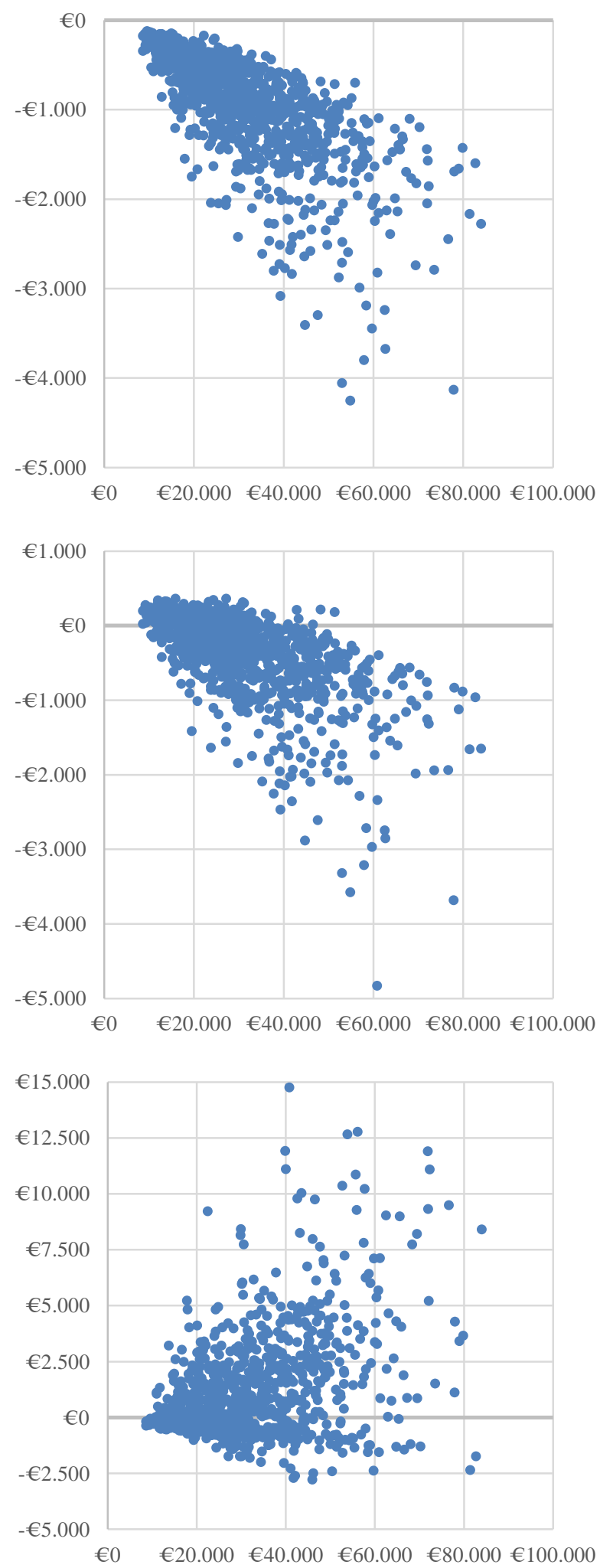
Table 3: Percentage of households benefitting (with positive equivalent variation)

\begin{tabular}{|l|c|c|c|c|c|}
\hline & All HH & Rural HH & $\begin{array}{c}\text { HH head } \\
\text { male }\end{array}$ & $\begin{array}{c}\text { HH with } \\
\text { children }\end{array}$ & Single HH \\
\hline Carbon tax of $€ 50 / \mathrm{tCO}_{2}$ & \multicolumn{5}{|l}{} \\
\hline No recycling & $0 \%$ & $0 \%$ & $0 \%$ & $0 \%$ & $0 \%$ \\
\hline Carbon dividend, lump-sum & $29 \%$ & $29 \%$ & $31 \%$ & $31 \%$ & $22 \%$ \\
\hline Lowering income taxes & $55 \%$ & $56 \%$ & $59 \%$ & $53 \%$ & $53 \%$ \\
\hline
\end{tabular}

Not surprisingly, rebating revenue from the carbon tax as lump-sum transfers shifts the equivalent variations upward across all incomes, so everyone is better off compared to not recycling carbon tax revenue. The equivalent variations now range between $€-2,918$ and $€ 225$. A significant portion of households now benefit from the policy proposal compared to not having a carbon tax (see the portion above the zero-line in the middle panel of Figure 3(a)). Given that all households receive the same payment, low-income households benefit more as indicated by the negative trend, which becomes even more pronounced when plotted as shares of expenditure (see Table B.1 in Appendix B). Transfers are, however, too low to make more than half of households better off. Table 3 shows that only $29 \%$ of all households welcome this policy package, with support being higher under rural and single households.

If carbon tax revenue is used to cut income taxes across the board by $8 \%$, the distributional pattern across expenditure flips. Households with very large income tax bills gain up to $€ 12,385$ per year while those with low incomes loose up to $€-1,594$ in equivalent variation. This way of recycling carbon tax revenue clearly benefits the rich more than the poor. This is confirmed by Figure B.2, which reports equivalent variations against income.

Thus far we have looked at recycling via either; using all revenue to hand out an additional lump-sum transfer to all citizens or using all revenue to lower income taxes. Carbon tax revenue can also be recycled via a combination of transfers and across-the-board income tax cuts. Figure 6 displays the effects on the across-the-board income tax cuts, hours worked and emissions against the percentage of carbon tax revenue from a carbon tax of $€ 50$ per $\mathrm{tCO}_{2}$ that is recycled as lump-sum transfers. In panel (a) the normalised lump-sum transfer rises from €0 to $€ 288$ as the share of the carbon revenue allocated to such transfers rises from $0 \%$ to $100 \%$. As the percentage of carbon revenue handed out as transfers rises from 0 to $80 \%$, the acrossthe-board income tax cut declines from $8 \%$ to zero. If one recycles more than $80 \%$ of carbon tax revenue as transfers, income taxes must rise beyond their original level by up to $2 \%$. The reason for this is that carbon taxes increase the CPI and depress the real consumption wage, so 
lower labour supply (see ginger line in panel 6(b)) and taxable incomes. Tax receipts thus fall, and tax rates must rise to make up for the shrinking tax base. Panel 6(b) also indicates that recycling as transfers lowers emissions consistent with Table 2.

Figure 6: Recycling options of pricing carbon at $€ 50 / \mathrm{tCO}_{2}$ and their aggregate effects

(a) Recycling options for politicians

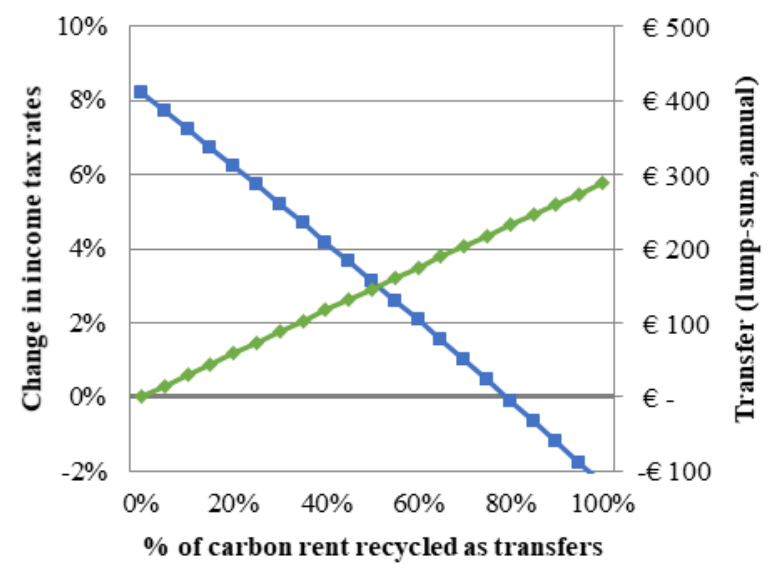

$\longrightarrow$ Reduction income tax (left) $\longrightarrow$ Lump sum transfer (right) (b) Aggregate effects across recycling options

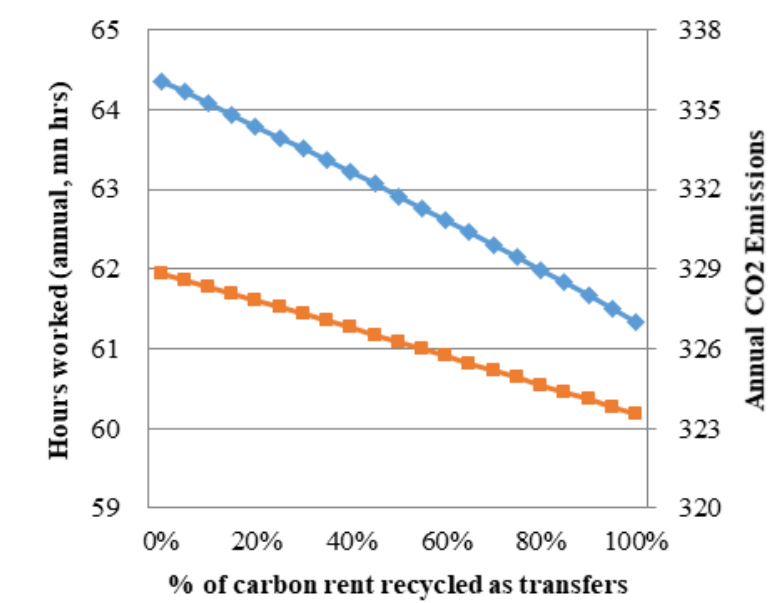

$\longrightarrow$ - Total hours worked (left) $\longrightarrow$ Annual CO2 emissions (right)

Figure 7 shows how these recycling schemes affect different household types and income groups. If less than $60 \%$ of carbon tax receipts are distributed as cash transfers, panel (a) indicates that more than half of households benefit from the carbon price of $€ 50$ per $\mathrm{tCO}_{2}$ (i.e. have positive equivalent variations). Higher levels of transfers generally depress the number of households that benefit from the green tax reform, although the relationship is not monotonic. Furthermore, the fraction of households that benefit from the reform, which we refer to as the “approval” rate, is relatively constant if transfers make up less than $60 \%$ of carbon tax revenue. If transfers make up a larger part of carbon revenue, approval rates plummet before stabilising around 30\%. This is a consequence of large parts of the population switching from benefiting to losing out from the green tax reform if recycling is such that the percentage revenue used to hand out lump-sum transfers rises from $60 \%$ to $80 \%$ (corresponding to an increase in the normalised lump-sum transfer from about 175 to 232 Euro per year) while the proportion of revenue used to cut income taxes drops correspondingly. Using all revenue for across-the-board income tax cuts maximises political support (with approval rates flat) if transfers make up less than $60 \%$ of revenue. If transfers make up more than $80 \%$ of carbon tax revenue, there is a concurrent increase in labour taxation (see Figure 6). Much of the discussion around the Yellow Vests movement has focused on the rural/urban divide. This aspect is only one of many and 
our simulations illustrate that approval rates do not vary across them. In the hypothetical scenario with exogenous labour supply, transfers are preferred over income tax cuts, with $60 \%$ of households better off in the case of recycling revenues as transfers and only $20 \%$ better off in the case of income tax cuts. This illustrates the importance of endogenous labour supply.

Figure 7: Approval of recycling schemes across household types and income groups

(a) Approval across household types

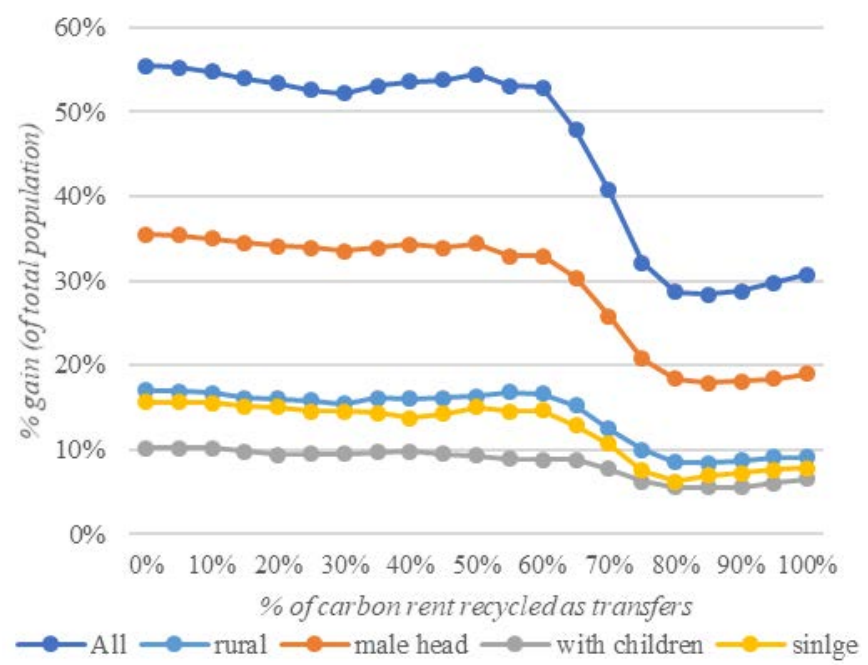

(b) Equivalent Variation across income groups

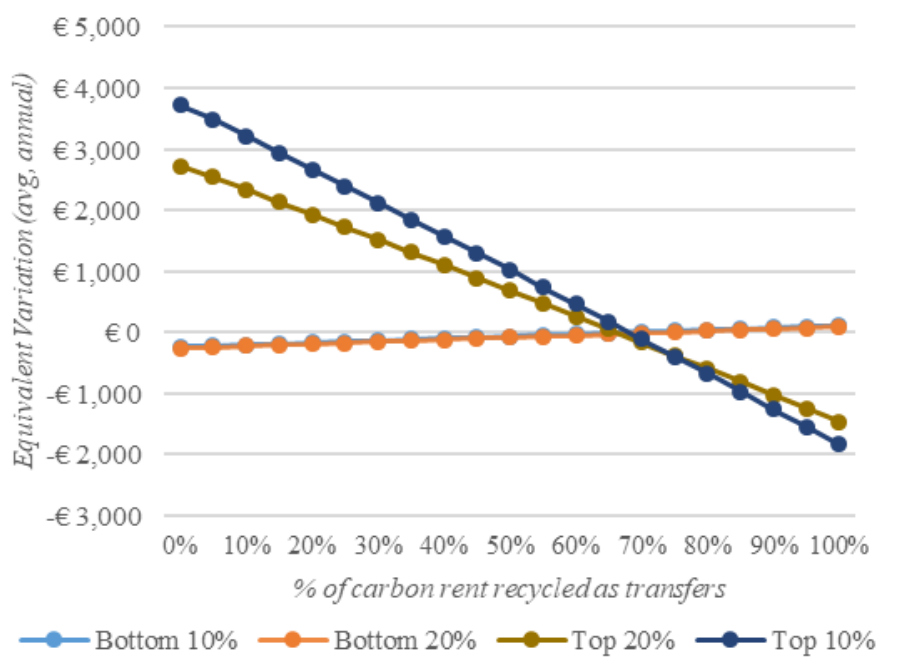

Panel 7(b) plots average equivalent variations for various income groups. Top earners benefit if carbon tax income is used to have across-the-board income tax cuts. Since virtually none of the bottom $10 \%$ of households earn enough to pay income taxes, they benefit (more) from transfers than from income tax cuts. The effect on the bottom $10 \%$ and $20 \%$ of the incomes is almost indistinguishable. Due to the skewedness of the income distribution, effects at the top are large. The distinct correspondence between a household's level of income and it being better off or not is partly due to our modelling of policy choices. Governments face a plurality of instruments. The correspondence, however, also demonstrates the importance of considering the varying impact of carbon pricing across the distribution of income.

\subsection{Different ways of implementing a $55 \%$ cut in emissions relative to 1990}

Here we investigate the effects of Germany meeting its legal target of reducing emissions by 55\% relative to their 1990 level (39\% reduction relative to their 2013 level). We let the carbon tax be whatever it needs to be to meet this target. Table 4 gives a summary of results. If carbon tax revenue is used to lower public debt, the carbon tax that is needed to achieve a $55 \%$ cut in emissions is lowest at $€ 99$ per $\mathrm{tCO}_{2}$. The effects are akin to the carbon tax with the same type of recycling discussed in section 5 . Higher goods prices lead to a fall in hours worked, incomes, 
and consumption. As before, all households are worse off under this policy and want to pay to avoid its implementation as the equivalent variations in the top panel of Figure 3(b) are all negative. The willingness to spend varies across households between $€ 121$ and $€ 5,435$ per year.

Table 4: Aggregates for 55\% emission reduction with different recycling schemes

\begin{tabular}{|c|c|c|c|c|c|}
\hline & $\begin{array}{c}\text { Carbon tax } \\
\left(€ / \mathrm{tCO}_{2}\right)\end{array}$ & $\begin{array}{l}\text { Hours worked } \\
\text { (million hours) }\end{array}$ & $\begin{array}{l}\text { Consumption } \\
\text { (billion Euro) }\end{array}$ & $\begin{array}{l}\text { GINI } \\
\text { income }\end{array}$ & $\begin{array}{c}\text { GINI } \\
\text { expenditure }\end{array}$ \\
\hline Baseline & - & 60,979 & 1,141 & 0.502 & 0.268 \\
\hline \multicolumn{6}{|c|}{ 55\% reduction in emissions relative to 1990} \\
\hline No recycling & 99 & $60,262-1.2 \%$ & $1,131-0.8 \%$ & 0.501 & 0.267 \\
\hline Carbon dividend, lump-sum & 103 & $60,272-1.2 \%$ & 1,153 & 0.501 & 0.264 \\
\hline Income tax cuts & 113 & 62,617 & 1,212 & 0.507 & 0.280 \\
\hline
\end{tabular}

Recycling the carbon tax back to households as a lump-sum transfer curbs labour supply by more, but boosts income, expenditure and, ultimately, carbon emissions. This is why the carbon tax must rise by more than if the carbon tax revenue is not recycled to ensure the same reduction in emissions. The required carbon tax must thus increase from $€ 99$ to $€ 103$ per $\mathrm{tCO}_{2}$, resulting in $€ 383$ in normalised transfer payments per year. Hours worked fall by $1.2 \%$ relative to the baseline due to the higher tax component in prices and the drop in real wages. Equivalent variations are again falling in expenditure. Households with low levels gain up to $€ 363$ per year relative to baseline, while some households would be willing to pay up to $€ 4,830$ per year to avoid the policy package. Table 5 shows that this policy would again be favoured only by $28 \%$ of households, with a large majority of each subcategory of all households objecting.

Recycling carbon tax revenue via lower income taxes affects income distribution adversely whilst such a green tax reform improves efficiency. The efficiency gains and increases in income at the top resulting from lowering progressive income taxes induce large rebound effects in carbon emissions due to the boost to labour supply.

Table 5: Percentage of households benefitting (i.e. with positive equivalent variation)

\begin{tabular}{|c|c|c|c|c|c|c|}
\hline & $\begin{array}{l}\text { Carbon tax } \\
\left(€ / \mathrm{tCO}_{2}\right)\end{array}$ & All HH & Rural HH & $\begin{array}{l}\text { HH head } \\
\text { male }\end{array}$ & $\begin{array}{l}\text { HH with } \\
\text { children }\end{array}$ & Single HH \\
\hline \multicolumn{7}{|c|}{ 55\% Reduction in emissions relative to 1990} \\
\hline No recycling & 99 & $0 \%$ & $0 \%$ & $0 \%$ & $0 \%$ & $0 \%$ \\
\hline Carbon dividend, lump-sum & 103 & $28 \%$ & $28 \%$ & $29 \%$ & $28 \%$ & $21 \%$ \\
\hline Income tax cuts & 113 & $55 \%$ & $55 \%$ & $59 \%$ & $52 \%$ & $53 \%$ \\
\hline
\end{tabular}


To cut emissions by 55\% relative to its 1990 level (39\% relative to 2013 levels) requires a larger carbon tax of $€ 113$ per $\mathrm{tCO}_{2}$ together with recycling via lowering income taxes by $14 \%$. Using carbon tax revenue to lower income taxes boosts hours worked by $2.7 \%$ and consumption in nominal terms by 6.3\%. Inequality in incomes and expenditure increases as top earners and spenders receive more money. Households at the top are willing to spend up to $€ 21,695$ to see such a green tax reform enacted, while those at the bottom are willing to spend up to $€ 2,786$ to avoid it. The regressive nature of this policy package is the opposite of a package where carbon tax revenue is recycled as lump-sum transfers (see Table B.2 in Appendix B including plots of equivalent variations against taxable income). Yet, more than half of households would be better off with this policy package for each subcategory.

If firms lower the carbon intensities of products in response to carbon taxes, consumer prices increase less for any given carbon tax and households' responses are more muted. We found that changes in aggregate hours worked and consumption are about a third higher across all recycling schemes when intensities are fixed. Firm-side responses to carbon taxes, thus, provide a compensating mechanism for the emissions-promoting effects of recycling carbon revenues. In their absence, the taxes necessary to reach an emissions target need to be higher, increasing the scope of recycling the resulting tax revenues.

\section{Discussion}

Our policy simulations for green tax reform take account of the government budget constraint and the estimated consumer demands and labour supply for each household. Taxes and transfers depend on household characteristics (e.g. number of dependent children, marital status, or retirement status). We assume that the government cannot hand out individualised lump-sum transfers and that the government can only scale the existing income tax system for Germany and we thus abstract from fully nonlinear and optimal tax systems. Our micro-based policy simulation model thus allows for the following channels by which a carbon tax cuts emissions: (i) curb demand for carbon-intensive and boost demand for carbon-extensive commodities (substitution effect), (ii) increase consumer prices, lower the real wage and thus lower labour supply and demand for all commodities including the carbon-intensive ones (output effect), and (iii) lower the emissions intensities (mitigation effect). Quantitatively, the mitigation effect has the largest effect on emissions, followed by the substitution effect while the output effect is small. Recycling options operate via income tax cuts blunting or reversing 
the output effect and via transfers also boosting demand and blunting the output effect. If policy could impact households differently, a more pronounced shift from carbon-intensive to carbonextensive households (composition effect) may be possible, but we have not explored this.

Raising transfer in a budget-neutral way via higher income taxes ensures a more equal income distribution. Figure 8 shows that if transfers are targeted more at the bottom of the income distribution (by adjusting weights $\varsigma_{h}$ ) the transfer can be larger. Political support or the share of households being better off as a result of the green tax reform first rises and then falls as the transfer is directed more and more at the lower incomes, where $100 \%$ corresponds to the case where all households are eligible (and the transfer is weighted by household size). If transfers are disbursed exclusively to the bottom $10 \%$, transfers outweigh the tax burden for those households but the remaining $90 \%$ are worse off as they are taxed but excluded from transfers.

\section{Figure 8: Transfers targeted to low-income households and political support}

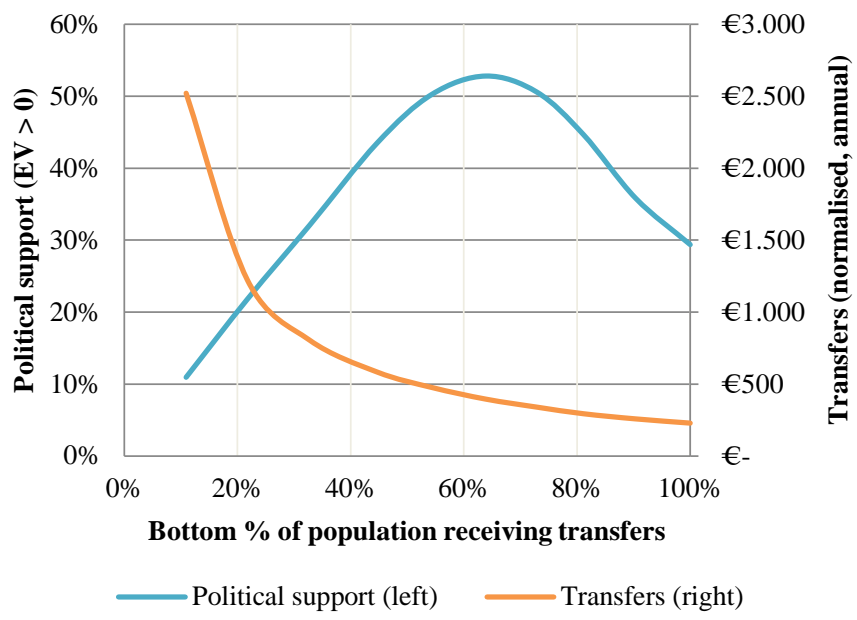

This logic of redistributing from the top to the bottom holds for the bottom $40 \%$ with the slope of the blue line in Figure 8 close to 1. If the group of eligible households is increased beyond that level, support flattens as higher income households, who consume more carbon and pay higher tax amounts, are included in the transfer scheme. Political support peaks at 53\% with the bottom $64 \%$ receiving transfers. After this, transfers become too diluted to maintain support which gradually falls to 29\% when all households receive transfers (as in the "Carbon dividend, lump-sum” scenario in Table 3).

Our empirical analysis indicates that carbon taxes are regressive with lower-income households spending a larger proportion on carbon-intensive goods. Pizer and Sexton (2019) also find this for the US. Flues and Thomas (2015) state that for the OECD lower-income households spend 
a higher share on electricity but not on transportation fuels (cf. Figure 1 for the Germany case). Cronin et al. (2019) use tax returns data and find that carbon taxes are progressive. Further, over a lifetime perspective and in general equilibrium the incidence of carbon taxes may be less regressive (e.g. Hassett et al., 2009; Rausch et al., 2011; Andersson and Atkinson, 2019). ${ }^{15}$ Horowitz et al. (2017) also study the distributional impact of recycling carbon tax revenue, but their focus is on the US and ours is on Germany. We find that far fewer people are better off (less than half instead of more than half) if all revenue is rebated as a carbon dividend. Klenert et al. (2018) do not have a micro-based simulation model and do not give any empirical calculations to examine the efficiency or inefficiency of a carbon dividend. We show that handing all revenue back as a carbon dividend necessitates higher income taxes and hurts efficiency.

There is a large literature on quantitative assessment of distributional effects within and across groups of carbon taxation and revenue recycling (e.g. Poterba, 1991; Metcalf, 1999; West and Williams, 2004; Bento et al., 2009; Grainger and Kohlstad, 2010; Rausch et al., 2011; Flues and Thomas, 2015; Williams et al., 2015; Rausch and Schwarz, 2016; Berry, 2019; Winter et al., 2019; Douenne, 2020). ${ }^{16}$ For example, Williams et al. (2015) find for the US that if revenue from a carbon tax is recycled to cut capital taxes the outcome is even more regressive, while recycling via lump-sum rebates is more progressive, albeit less efficient, and via a lower labour tax yields intermediate effects. Cronin et al. (2019) calculate the effects of a carbon tax and three recycling schemes for the US using tax returns matched to social security information and imputations from the Consumer Expenditure Survey. ${ }^{17}$ Our focus is different from this literature in that we analyse the effects of emission reduction targets as well as carbon taxes on the political calculus of green tax reform.

Our analysis can be improved in various ways. First, we could allow for both external and internal margins in labour supply and study transfers such as the earned income tax credit that

\footnotetext{
${ }^{15}$ More recently, general equilibrium analysis has been used to study the general equilibrium effects of an efficient energy standard (Fullerton et al., 2016) and the distributional and the transitional labour market dynamics effects of environmental regulation across workers (e.g. Hafstead and Williams, 2018, 2020). Large negative impacts are concentrated among workers initially employed in a few carbon-intensive industries. It has also been found that indexing transfers reduces the regressivity of the carbon tax (Fullerton et al., 2012).

${ }^{16}$ Pizer and Sexton (2019) review the distributional impacts of energy taxes and conclude that they may be less regressive depending on how energy tax revenues are used and on the physical, social, and climatic characteristics of the jurisdictions in which they are implemented. They also show that the variation in household energy expenditure is greater within, than across, income groups and that such variation is not easily reduced.

17 They find that the carbon tax burden is progressive and rebating lump-sum transfers makes it more progressive but do not consider the behavioural changes in disaggregated demand for the different commodities or in labour supply. They also find that horizontal redistributions within deciles exceeds vertical distributions between deciles.
} 
avoid poverty traps and improve efficiency (e.g. Saez, 2002). Second, more work is needed on "waterbed" effects resulting from the interaction of carbon prices in Europe with the EU Emissions Trading Scheme permit prices and existing transport fuel taxes and other overlapping climate policies (e.g. Perino et al. 2019). Third, it is important to investigate how supply-side distortions, overlapping generations and lifecycle effects, and general equilibrium affect the political calculus. Fourth, environmental quality affects households differently (i.e. the $\psi_{\mathrm{h}}$ in (7) vary) as the poor are hurt more by pollution and climate change than the rich. ${ }^{18}$ It is important to obtain reliable estimates for damages at the household level for Germany as these would affect utilities of households and thus the political calculus. ${ }^{19}$ Fifth, our case of no recycling implies that the revenue is spent on wasteful government spending and use this artefact to decompose the different effects of transfers versus lower income taxes. If revenue is spent on, say, social welfare, trains, or coal plants, there will consequently be equity, multiplier, efficiency, and emissions effects. If revenue is used to cut public debt, there will be positive effects on the welfare of future generations. ${ }^{20}$ Sixth, one could allow leisure to be a complement or substitute with consumption commodities. ${ }^{21}$ For example, West and Williams (2007) find that leisure and consumption goods are complementary and that this pushes the optimal gasoline tax significantly above the Pigouvian tax. Finally, our results and policy messages apply to Germany and more studies are needed on green tax reform and political support in other countries such as France and its Yellow Vest movement.

A natural step forward is to investigate optimal recycling of carbon taxes using a social welfare function which gives a higher weight to poorer than richer households. In fact, the pre-existing German tax system implies a certain taste for fairness and income redistribution. We know of no revealed preference study for Germany, but Jacobs, et al. (2017) analyse election manifestos and find that all political parties give a higher political weight to middle incomes than to the poor and almost no weight to the rich. They find that these weights are very close to the weights

\footnotetext{
18 The Pigouvian carbon tax would then need to be equity-weighted (e.g. Mirrlees, 1978; Anthoff et al. 2009; Jacobs and van der Ploeg, 2019) and would typically be higher.

${ }^{19}$ Given that damages enter utility separately, they do not affect emissions, hours worked, consumption, commodity demands, and tax revenues but do affect utility. We have reported for each type of household the equivalent variations (12) minus the disutility cost of labour. If the government wants to maximise social welfare, it needs to take a stance on the precise damages.

${ }^{20}$ Kotlikoff et al. (2021) show that to ensure all generations benefit the public debt needs to rise to allow transfers from future to current generations.

${ }^{21}$ Uniform commodity taxation is then no longer optimal, since this requires leisure to be weakly separable from consumption in the utility function (Atkinson and Stiglitz, 1976). This implies that commodity taxation should not be used to have a fairer income distribution if leisure is weakly separable from consumption. Kaplow (2006) shows that this is even so if income taxation is not optimal. In our context, this means it is optimal to direct the pollution tax entirely at internalising externalities, not at raising revenue or making the distribution more equal.
} 
implied by the pre-existing tax system. One could thus infer the welfare weights for each household to match the existing progressivity of the German tax system and use these to analyse optimal recycling of carbon tax revenue, but we must leave this for future research.

Our analysis has focused on the feasibility of green tax reform. A next step is the investigatation of the optimal carbon tax. This would extend the old double dividend literature on green tax reform (Bovenberg and de Mooij, 1994; Bovenberg and van der Ploeg, 1994, 1998ab; Goulder, 1995; Bovenberg, 1999) ${ }^{22}$ from homogenous to heterogenous agents and allow a discussion of the optimal trade-off between equity, efficiency, and environmental quality. However, with heterogenous households and a government that optimally pursues the objectives of combatting pollution and an equitable income redistribution, the marginal cost of funds equals exactly one and the optimal carbon tax equals the Pigouvian tax and should thus not be directed at distributional objectives, provided the optimal tax system is fully nonlinear (Cremer et al., 1998, 2003; Jacobs and the Mooij, 2015) or the tax system is linear and preferences are of the Gorman polar form with linear Engel curves as in the Linear Expenditure System (Jacobs and van der Ploeg, 2019). Our policy exercises share, with this literature, the concern with the distributional impact but focus on green tax reform and how recycling can improve the political acceptability of such reforms and not with optimal pollution and income distribution policies.

\section{Concluding remarks}

The European Union has committed itself to achieving carbon neutrality by mid-century and in 2021 Germany introduced a carbon tax of $€ 50$ per ton of CO2. While the willingness of European governments to implement stringent climate policy is unwavering, that of the populace is not. We, therefore, study the impact of carbon taxation across the income distribution. To achieve this, household heterogeneity must be taken into account at the design stage of green tax reforms to establish which households are better and which are worse off.

Our policy simulations suggest that recycling all revenue from a carbon tax via lowering income taxes is not only efficient in that it boosts employment and consumer spending, but this policy package can also count on the support of more than half the population. However, the

\footnotetext{
${ }^{22}$ Some insights are that using the revenue from a pollution tax to lower the income tax cuts emissions but need not boost employment unless green tax reform starts out from low pollution taxes and high income tax rates. Such a green tax reform depresses the marginal cost of public funds and boosts public spending provided elasticities of substitution between clean and dirty commodities are low enough. Carbon tax increases are then a very efficient way of raising public revenue.
} 
problem with this package is that the poorest people will be worse off. If the government or voters care about equity, recycling part of the revenue as lump-sum transfers lessens the adverse effects on the poorer segments of society. Our results suggest that more than half of the population will still support the green tax reform, provided this part does not exceed about $60 \%$. If more than $80 \%$ of carbon revenue is rebated as transfers, labour supply and the income taxes fall far enough for it to be necessary to raise income taxes. Hence, rebating all of carbon revenue as a visible carbon dividend is an unwise option, as it requires higher income taxes and reduces economic activity substantially. More importantly, about $70 \%$ of the population will be worse off under such a green tax reform.

The details of a green tax reform matter greatly for their environmental, economic and distributional outcomes. While funnelling receipts from a carbon tax of $€ 50$ per $\mathrm{tCO}_{2}$ into the general budget lowers emissions from households by 26\%, a recycling of these funds by lowering income taxes by $8 \%$ across the board would yield a reduction of $24 \%$, with the reduction due to households cut in less than half. Since lower income taxes boost efficiency and employment, there is a clear trade-off between environmental and economic outcomes. Both types of recycling hurt the poor at the bottom end of the income distribution. While all households lose in the absence of transfers, those at the top gain significantly under the recycling via lowering of income taxes. If carbon tax revenues are paid out uniformly to all households in the form of a normalised climate dividend of $€ 229$ per year, those at the bottom benefit relatively more and the distribution of income becomes more equal. This creates a second trade-off between economic and distributional outcomes. Generally, the approval rate for a carbon tax of $€ 50$ per $\mathrm{tCO}_{2}$ hovers around $55 \%$ provided that $60 \%$ or less of revenue is recycled as lump-sum transfers. Similar insights hold for the case when governments strive for a target reduction in aggregate emissions, e.g. as specified in the Paris Treaty within the United Nations Framework Convention on Climate Change (ratified in 2016).

Our policy simulation results suggest that it is important to avoid misleading policy insights by taking account of endogenous labour supply when considering how to recycle carbon tax revenue. Furthermore, most of the emission reductions stem from the supply side rather than from the demand side as the price elasticities of demand are relatively modest while producers respond more easily by adjusting emission intensities of their products.

Paoli (2021) and Paoli and van der Ploeg (2021) discuss a similar exercise using the same methodology to obtain a better understanding of the different ways of recycling carbon tax revenue has on efficiency and on horizontal and vertical equity in the United Kingdom. Their 
main finding is that the preferred way of recycling carbon tax revenue from an equity and political perspective for the United Kingdom is to use the revenue to increase social security benefits. This ensures that $35 \%$ of households are better off. If the revenue is used to finance per-capita transfers or to cut income taxes, only 19\% and 11\% respectively of households are better off. So, although we can find a recycling packing that ensures that most households are better off in Germany, this is not feasible for the United Kingdom. On the other hand, Horowitz et al. (2017) find that for the United States recycling of carbon tax revenue as lump-sum transfers makes $70 \%$ of people better off, but they use a different methodology which does not trace the detailed effects of policy on commodity demand and labour supply, and they do not rely on equivalent variations. Our results and these studies indicate that one cannot make blanket statements about policy that hold for all countries. The specifics of demand for individual commodities and labour supplies and the methodology used matter for the evaluation of various ways of recycling carbon tax revenue.

We want to highlight one final issue. Douenne and Fabre (2021) investigate attitudes and beliefs during the Yellow Vests movement in France against carbon taxation and find that the French reject carbon taxation even if the revenue is redistributed uniformly to all households. Our results suggest that this may be rational, since we find that the overwhelming majority would be worse off under such a green tax reform, at least in Germany. They also suggest that the French over-estimate the negative impact of carbon pricing on their purchasing power and do not perceive it to be effective in terms of curbing emissions. Correcting these behavioural biases might generate a majority in favour of green tax reform in France too, albeit only a small minority might be convinced. ${ }^{23}$ An alternative approach for policy makers is to take these behavioural biases as given and design green tax reform accordingly. Farhi and Gabaix (2020) extend the theories of optimal Ramsey, Pigouvian and Mirrleesian taxation to allow for behavioural agents with misperception and other biases and analyse both taxes and nudges. For example, Pigouvian taxes are now the marginal value of the damages divided by the attention, so they are much lower if policy makers take account of the Yellow Vests movement. ${ }^{24}$ Nudges help to target internalities whilst avoiding adverse income distributional consequences. In future work it is therefore important to allow for these behavioural biases when analysing optimal green tax reforms and the accompanying nudges that will be needed.

\footnotetext{
${ }^{23}$ Douenne and Fabre (2020) show that there is majority support for green investments and advocate information campaigns for climate awareness.

${ }^{24}$ Furthermore, the Ramsey rule is modified so that taxes are proportional to the attention squared and inversely proportional to the elasticity of demand.
} 


\section{References}

Andersson, J. and G. Atkinson (2019). The distributional effects of a carbon tax: the role of income inequality, Centre for Climate Change Economics and Policy Working Paper No. 378, London School of Economics and Political Science.

Anthoff, D., C. Hepburn and R.S.J. Tol (2009). Equity weighting and the marginal damage costs of climate change, Ecological Economics, 68, 3, 836-849.

Atkinson, A.B. (1970). On the measurement of inequality, Journal of Economic Theory, 2, 3, 244-263.

Atkinson, A.B. and J.E. Stiglitz (1976). The design of tax structure: direct versus indirect taxation, Journal of Public Economics, 6, 55-75.

Banks, J., R. Blundell and A. Lewbel (1997). Quadratic Engel curves and consumer demand, Review of Economics and Statistics, 79, 49, 527-539.

Bargain, O., K. Orsini and A. Peichl (2014). Comparing labor supply elasticities in Europe and the United States: new results, Journal of Human Resources, 49, 723-838

Bento, A., L. Goulder, M. Jacobson and R. von Haefen (2009). Distributional and efficiency impacts of increased US gasoline taxes, American Economic Review, 99, 3, 667-699.

Berry, A. (2019). The distributional effects of a carbon tax and its impact on fuel poverty: a micro-simulation study in the French context, Energy Policy, 124, 81-94.

Bovenberg. A.L. (1999). Green tax reforms and the double dividend: an updated reader's guide, International Tax and Public Finance, 6, 3, 421-443.

Bovenberg, A.L. and R.A. de Mooij (1994). Environmental levies and distortionary taxation, American Economic Review, 84, 4, 1085-1089.

Bovenberg, A.L. and F. van der Ploeg (1994). Environmental policy, public finance and the labour market in a second-best world, Journal of Public Economics, 55, 349-390.

Bovenberg, A.L. and F. van der Ploeg (1998a). Consequences of environmental tax reform for unemployment and welfare, Environmental and Resource Economics, 12, 2, 137-150.

Bovenberg, A.L. and F. van der Ploeg (1998b). Tax reform, structural unemployment and the environment, Scandinavian Journal of Economics, 100, 3, 593-610.

Cremer, H., F. Gahvari and N. Ladoux (1998). Externalities and optimal taxation, Journal of Public Economics, 70, 3, 343-364.

Cremer, H., F. Gahvari and N. Ladoux (2003). Environmental taxes with heterogenous consumers: an application to energy consumption in France, Journal of Public Economics, 87, 12, 2791-2815.

Cremer, H., J. Lozachmeur, D. Maldonado and K. Roeder (2016). Household bargaining and the design of couples' income taxation, European Economic Review, 89(C), 454-470.

Cronin, J.A., D. Fullerton and S. Sexton (2019). Vertical and horizontal distributions from a carbon tax and rebate, Journal of the Association of Environmental and Resource Economists, 6, 169-208.

Deaton, A. and J. Muellbauer (1980). An almost ideal demand system, American Economic Review, 70, 3, 312-326.

Destatis (2019). Federal Statistical Office, Direct and indirect CO2-emissions in Germany 2010 - 2015. https://www.destatis.de/EN/Themes/Society-Environment/ 
Environment/Material-Energy-Flows/Publications/Downloads-Material-EnergyFlows/co2-emissions-pdf-5851306199004.pdf?_blob=publicationFile

Douenne, T. (2020). The vertical and horizontal distributive effects of energy taxes: a case study of a French policy, The Energy Journal, 41, 3.

Douenne, T. and A. Fabre (2020). French attitudes on climate change, carbon taxation, and other climate policies, Ecological Economics, 169, 106496.

Douenne, T. and A. Fabre (2021). Yellow vests, pessimistic beliefs, and carbon tax aversion,American Economic Journal: Economic Policy, forthcoming.

Fadlon I. and Nielsen T. H. (2019). Household labor supply and the gains from social insurance, Journal of Public Economics, 171, 18-28.

Farhi, E. and X. Gabaix (2020). Optimal taxation with behavioural agents, American Economic Review, 110, 1, 298-336.

Flues, F. and A. Thomas (2015). The distributional effects of energy taxes, Technical Report 23, OECD, Paris.

Fullerton, D., G. Heutel and G. Metcalf (2012). Does the indexing of government transfers make carbon pricing progressive?, American Journal of Agricultural Economics, 94, 2, 347-353.

Goulder, L. (1995). Environmental taxation and the double dividend: a reader's guide, International Tax and Public Finance, 2, 2, 157-183.

Goulder, L., M.A.C. Hafstead and R.C. Williams III (2016). General equilibrium impacts of an Federal clean energy standard, American Economic Journal: Economic Policy, 8, 2, 186-218.

Grainger, C. and C. Kohlstad (2010). Who pays a price on carbon, Environmental and Resource Economics, 46, 3, 359-376.

Hafstead, M.A.C. and R.C. Williams III (2018). Unemployment and environmental regulation in general equilibrium, Journal of Public Economics, 160, 50-65.

Hafstead, M.A.C. and R.C. Williams III (2020). Distributional effects of environmental regulation across workers: a general equilibrium analysis, Resources for the Future.

Hardadi, G., A. Buchholz and S. Pauliuk (2020). Implications of the redistribution of German household environmental footprints across income groups for integrating environmental and social policy design, Industrial Ecology, 25, 95-113.

Hassett, K.A., A. Mathur and G.E. Metcalf (2009). The incidence of a U.S. carbon tax: a lifetime and regional analysis, The Energy Journal, 0, 2, 155-178.

Heathcote, J., K. Storesletten and G.L. Violante (2017). Optimal tax progressivity: an analytical framework, Quarterly Journal of Economics, 16, 1693-1754.

Heckman, J. (1979). Sample selection bias as a specification error, Econometrica, 47, 1, 153161.

Horowitz, J.L. (2001). The bootstrap, in J. Heckman and E. Leamer (eds.), Handbook of Econometrics, Volume 5, Elsevier Amsterdam.

Horowitz, J. , J.-A. Cronin, H. Hawkins, L. Konda and A. Yuskavage (2017). Methodology for analyzing a carbon tax, Working Paper 115, Office of Tax Analysis, Department of the Treasury.

Jacobs, B. and R.A. de Mooij (2015). Pigou meets Mirrlees, Journal of Environmental Economics and Management, 71, C, 90-108. 
Jacobs, B. and F. van der Ploeg (2019). Redistribution and pollution taxes with non-linear Engel curves, Journal of Environmental Economics and Management, 95, 198-226.

Jacobs, B., E.L.W. Jongen and F.T. Zoutman (2017). Revealed social preferences of Dutch political parties, Journal of Public Economics, 165, 81-100.

Kaplow, L. (2006). On the undesirability of commodity taxation even when income taxation is not optimal, Journal of Public Economics, 90, 6-7, 1235-1250.

Klenert, D., L. Mattauch, E. Combet, O. Edenhofer, C. Hepburn, R. Rafaty and N. Stern (2018). Making carbon pricing work for citizens, Nature Climate Change, 8, 669-677.

Kotlikoff, L., F. Kubler, A. Polbin, J. Sachs and S. Scheidegger (2021). Making carbon taxation a generational win win, International Economic Review, 62, 1, 3-46.

LaLumia, S. (2008). The effects of joint taxation of married couples on labor supply and nonwage income, Journal of Public Economics, 92, 7, 1698-1719.

Lewbel, A. (1989). Identification and estimation of equivalence scales under weak separability, Review of Economic Studies, 56, 311-316.

Lewbel, A. and K. Pendakur (2009). Tricks with Hicks: the EASI demand system, American Economic Review, 99, 827-863.

Loeffler, M., A. Peichl, N. Pestel, S. Siegloch and E. Sommer (2014). Documentation IZA YMOD v.3: The IZA policy simulation model, IZA Discussion Paper 8553, IZA.

Mayer, H. and C. Flachmann (2011). Extended input-output model for energy greenhouse gases, Environmental-Economic Accounting, Federal Statistical Office, Germany.

Metcalf, G. (1999). A distributional analysis of green tax reforms, National Tax Journal, 52, 4, 655-682.

Mirrlees, J.A. (1978). Social benefit-cost analysis and the distribution of income, World Development, 6, 2, 131-138.

Nikodinoska, D. and C. Schröder (2016). On the emissions-quality and emissions-welfare trade-offs in energy taxation: evidence on the German fuels tax, Resource and Energy Economics, 44, 206-233.

Nordhaus, W. (2017). Revisiting the social cost of carbon, Proceedings of the National Academy of Sciences, 114 (7), 1518-1523.

Paoli, M.C. (2021). Political feasibility and distributional implications of carbon pricing: the scope for revenue recycling, MPhil thesis, Department of Economics, University of Oxford.

Paoli, M.C. and F. van der Ploeg (2021). Recycling revenue to improve political feasibility of carbon pricing in the United Kingdom, 4 October, VoxEU, https://voxeu.org/article/recycling-revenue-improve-political-feasibility-carbonpricing-uk

Perino, G., R.A. Ritz and A. van Benthem (2019). Overlapping climate policies, Working Paper 25643, NBER, Mass.

Pizer, W.A. and S. Sexton (2019). The distributional impacts of energy taxes, Review of Environmental Economics and Policy, 13, 1, 104-123.

Pollak, R.A. and T.J. Wales (1981). Demographic variables in demand analysis, Econometrica, 49, 6, 1533-1551.

Poterba, J. (1991). Is the gasoline tax regressive?, Tax Policy and the Economy, 5, 145-164. 
Pothen, F. and M.A. Tovar (2018). The distribution of material footprints in Germany, Ecological Economics, 153, 237-251.

Rausch, S. and G.A. Schwarz (2016). Household heterogeneity, aggregation and the distribution of environmental taxes, Journal of Public Economics, 138, 43-57.

Rausch, S., G.E. Metcalf and J.M. Reilly (2011). Distributional impacts of carbon pricing: a general equilibrium approach with micro-data for households, Energy Economics, 33, 3, S20-33.

Tovar, M.A. and N.M. Wölfing (2018). Household energy prices and inequality: evidence from German microdata based on the EASI demand system, Energy Economics, 70, 84-97.

Saez, E. (2002). Optimal income transfer programs: intensive versus external labour supply responses, Quarterly Journal of Economics, 117, 3, 1039-1073.

West, S.E. and R.C. Williams (2004). Estimates from a consumer demand system: implications for the incidence of environmental taxes, Journal of Environmental Economics and Management, 47, 3, 535-558.

West, S.E. and R.C. Williams (2007). Optimal taxation and cross-price effects on labor supply: estimates of the optimal gas tax, Journal of Public Economics, 91, 3-4, 593-617.

Williams, R.C, H. Gordon, D. Burtraw, J. Carbon and R.D. Morgenstern (2015). The initial incidence of a carbon tax across income groups, National Tax Journal, 68, 1, 195-214.

Winter, J., B. Dolter and G.K. Fellows (2019). Carbon pricing for household and revenue cycling options in Canada, mimeo., School of Public Policy, University of Calgary. 


\section{Appendix A: Description of data and estimates of the demand system and labour supply}

The German Einkommens- und Verbrauchsstichprobe (Survey of Incomes and Expenditures or EVS) is used to estimate the EASI demand system and labour supply. It provides information on expenditures across goods and other socio-economic variables and is one of Germany's chief microeconomic datasets. The survey is carried out every five years. We follow the methodology of Lewbel (1989) to obtain household-specific commodity prices by combining the micro data with prices reported by the German Statistical Office. The top panel of Table A.1 gives summary statistics the demand system data based on the EVS's of 1993, 1998, 2003, 2008 and 2013 with mean total consumer expenditure 7,824 Euro per quarter and standard deviation 4,039 Euro per quarter. The bottom panel gives labour market data for households with one or two members working based on the EVS's of 2003, 2008 and 2013 (data quality of waves 1993 and 1998 is not sufficient for inclusion in labour supply estimation).

Table A.1: Descriptive statistics for the demand and labour supply variables

\begin{tabular}{|c|c|c|c|c|}
\hline & Mean & SD & Min & Max \\
\hline \multicolumn{5}{|c|}{ Demand system estimation } \\
\hline \multicolumn{5}{|l|}{ Budget shares } \\
\hline Food & 0.172 & 0.065 & 0.044 & 0.389 \\
\hline Housing & 0.273 & 0.089 & 0.080 & 0.554 \\
\hline Electricity & 0.026 & 0.013 & 0.006 & 0.085 \\
\hline Heating & 0.043 & 0.029 & 0.003 & 0.204 \\
\hline Transport & 0.086 & 0.042 & 0.015 & 0.244 \\
\hline Service & 0.091 & 0.074 & 0.007 & 0.440 \\
\hline Durable & 0.075 & 0.045 & 0.004 & 0.230 \\
\hline Others & 0.233 & 0.104 & 0.035 & 0.584 \\
\hline \multicolumn{5}{|l|}{ Logarithm of prices } \\
\hline Food & 4.461 & 3.079 & 3.970 & 5.053 \\
\hline Housing & 3.640 & 3.122 & -0.983 & 5.042 \\
\hline Electricity & 4.397 & 3.091 & 4.131 & 4.818 \\
\hline Heating & 3.320 & 2.453 & 2.308 & 4.791 \\
\hline Transport & 4.140 & 2.981 & 2.645 & 5.302 \\
\hline Service & 3.912 & 2.766 & 2.312 & 4.783 \\
\hline Durable & 4.271 & 2.938 & 2.371 & 4.905 \\
\hline Others & 3.888 & 2.753 & 2.492 & 4.699 \\
\hline \multicolumn{5}{|c|}{ Other variables included in the estimation } \\
\hline Total Expenditure (Euro) & 7824 & 4040 & 1776 & 24,929 \\
\hline Dummy if central heating & 0.757 & 0.429 & 0.000 & 1.000 \\
\hline Dummy if district heating & 0.175 & 0.380 & 0.000 & 1.000 \\
\hline Dummy if building date 1948 & 0.1713 & 0.3768 & 0.0000 & 1.0000 \\
\hline Dummy if building date 1949-1990 & 0.4827 & 0.4997 & 0.0000 & 1.0000 \\
\hline Dwelling size (squared meters) & 99.039 & 40.781 & 10.000 & 500.000 \\
\hline Dummy if below 20k inhabitants & 0.148 & 0.355 & 0.000 & 1.000 \\
\hline Dummy if $20 \mathrm{k}$ - $100 \mathrm{k}$ inhabitants & 0.258 & 0.438 & 0.000 & 1.000 \\
\hline Number of observations & 121,280 & & & \\
\hline
\end{tabular}


Table A.1 (cont'd): Descriptive statistics for the demand and labour supply variables

\begin{tabular}{|lcrrr|}
\hline & Mean & SD & Min & Max \\
\hline & Labour supply & & & \\
Hours worked per week & 50.076 & 19.022 & 1.000 & 96.000 \\
Income from labour (€ per week) & 1094 & 646 & 5.083 & 7914 \\
Dummy if rural household & 0.317 & 0.465 & 0.000 & 1.000 \\
Dummy if male head of household & 0.651 & 0.477 & 0.000 & 1.000 \\
Dummy if dependent children & 0.311 & 0.463 & 0.000 & 1.000 \\
Dummy if one-member household & 0.231 & 0.422 & 0.000 & 1.000 \\
Number of observations & 30894 & & & \\
\hline
\end{tabular}

Key: Dummies are 1 if the condition is satisfied and zero otherwise.

Table A.2: Distribution of household types in the sample

\begin{tabular}{|lrr|}
\hline & Observations & Percent \\
\hline Other households & 17,277 & 14.25 \\
Single +65, no children & 10,259 & 8.46 \\
Single, no children & 16,323 & 13.46 \\
Single, children & 14,380 & 11.86 \\
2 adults +65, no children & 7,987 & 6.59 \\
2 adults, no children & 26,765 & 22.07 \\
2 adults, one child & 14,928 & 12.31 \\
2 adults, two children & 13,361 & 11.02 \\
Number of observations & 121,280 & \\
\hline
\end{tabular}

Table A.3 below reports estimates of the EASI demand system (5), Table A.4 and A.5 give the own price elasticities for the first and last expenditure quartile, Table A.6 gives the expenditure elasticities, and Table A.7 gives the econometric estimate of the labour supply function (8).

The restrictions summarized in equation (3) apply. For example, the rows from the first panel of Table A.3 display the own price coefficients $\left(a_{i i}\right)$ which sum up to zero. Also, the first row under the heading "Polynomial Coefficients $\left(b_{i r}\right)$ " sum up to one while the following rows add up to zero. Furthermore, the rows under the heading "Indirect utility interaction with socioeconomic coefficients" $\left(d_{i k}\right)$ sum up to zero.

The dependent variables are the budget shares for the commodities along the 7 columns. The reported estimated coefficients correspond to those in equation (5), repeated here

$$
w_{h i}=\sum_{r=0}^{R} b_{i r} \log \left(v_{h}\right)^{r}+\sum_{j=1}^{I} a_{i j} \log \left(q_{h i}\right)+\sum_{k=1}^{K}\left[d_{i k} z_{h k} \log \left(v_{h}\right)+g_{i k} z_{h k}\right] .
$$

Tables A.4, A.5 and A.6 present price and expenditure elasticities that are computed using the expressions $\frac{\partial \log \left(w_{i}\right)}{\partial \log \left(q_{j}\right)}-\delta_{i j}=\varepsilon_{i j}$ and $\frac{\partial \log \left(w_{i}\right)}{\partial \log (y)}+1=\varepsilon_{i}$, where $\delta_{i j}$ is the Kronecker delta and takes on 1 if $i=j$ and 0 otherwise (Banks et al. ,1997) given the budget share equations (1) or (A1). 
Table A3: Main estimated coefficients for the estimated EASI demand system (1')

\begin{tabular}{|c|c|c|c|c|c|c|c|c|}
\hline & Food & Housing & Electricity & Heating & Transport & Service & Durable & Others \\
\hline \multicolumn{9}{|c|}{ Price coefficients $\left(a_{i j}\right)$} \\
\hline Food & $\begin{array}{c}0.0629 * * * \\
(0.0007)\end{array}$ & $\begin{array}{c}-0.0186 * * * \\
(0.0004)\end{array}$ & $\begin{array}{c}-0.0006 * * * \\
(0.0002)\end{array}$ & $\begin{array}{c}0.0008^{* *} \\
(0.0003)\end{array}$ & $\begin{array}{c}-0.001^{* *} \\
(0.0004)\end{array}$ & $\begin{array}{c}-0.0083 * * * \\
(0.0005)\end{array}$ & $\begin{array}{c}-0.0144 * * * \\
(0.0004)\end{array}$ & $\begin{array}{c}-0.0207^{* * *} \\
(0.0005)\end{array}$ \\
\hline Housing & $\begin{array}{c}-0.0186 * * * \\
(0.0004)\end{array}$ & $\begin{array}{c}0.0438 * * * \\
(0.0007)\end{array}$ & $\begin{array}{c}-0.0019 * * * \\
(0.0001)\end{array}$ & $\begin{array}{c}0.0014 * * * \\
(0.0003)\end{array}$ & $\begin{array}{c}-0.0063 * * * \\
(0.0003)\end{array}$ & $\begin{array}{c}0.0043^{* * * *} \\
(0.0004)\end{array}$ & $\begin{array}{c}-0.0041 * * * \\
(0.0003)\end{array}$ & $\begin{array}{c}-0.0186 * * * \\
(0.0005)\end{array}$ \\
\hline Electricity & $\begin{array}{c}-0.0006 * * * \\
(0.0002)\end{array}$ & $\begin{array}{c}-0.0019 * * * \\
(0.0001)\end{array}$ & $\begin{array}{c}0.0169 * * * \\
(0.0004)\end{array}$ & $\begin{array}{c}-0.003^{* * *} \\
(0.0002)\end{array}$ & $\begin{array}{c}-0.0008 * * * \\
(0.0001)\end{array}$ & $\begin{array}{c}-0.0023 * * * \\
(0.0001)\end{array}$ & $\begin{array}{c}-0.0027 * * * \\
(0.0001)\end{array}$ & $\begin{array}{c}-0.0054^{* * *} \\
(0.0001)\end{array}$ \\
\hline Heating & $\begin{array}{c}0.0008 * * \\
(0.0003)\end{array}$ & $\begin{array}{c}0.0014^{* * *} \\
(0.0003)\end{array}$ & $\begin{array}{c}-0.003 * * * \\
(0.0002)\end{array}$ & $\begin{array}{c}0.0144 * * * \\
(0.0003)\end{array}$ & $\begin{array}{c}-0.0018 * * * \\
(0.0002)\end{array}$ & $\begin{array}{c}-0.001 * * * \\
(0.0003)\end{array}$ & $\begin{array}{c}-0.0036 * * * \\
(0.0003)\end{array}$ & $\begin{array}{c}-0.0072 * * * \\
(0.0003)\end{array}$ \\
\hline Transport & $\begin{array}{l}-0.001 * * \\
(0.0004)\end{array}$ & $\begin{array}{c}-0.0063 * * * \\
(0.0003)\end{array}$ & $\begin{array}{c}-0.0008 * * * \\
(0.0001)\end{array}$ & $\begin{array}{c}-0.0018 * * * \\
(0.0002)\end{array}$ & $\begin{array}{c}0.0119 * * * \\
(0.0004)\end{array}$ & $\begin{array}{c}-0.0033^{* * *} \\
(0.0003)\end{array}$ & $\begin{array}{c}-0.0029 * * * \\
(0.0003)\end{array}$ & $\begin{array}{c}0.0042 * * * \\
(0.0004)\end{array}$ \\
\hline Service & $\begin{array}{c}-0.0083^{* * *} \\
(0.0005)\end{array}$ & $\begin{array}{c}0.0043^{* * *} \\
(0.0004)\end{array}$ & $\begin{array}{c}-0.0023 * * * \\
(0.0001)\end{array}$ & $\begin{array}{c}-0.001 * * * \\
(0.0003)\end{array}$ & $\begin{array}{c}-0.0033 * * * \\
(0.0003)\end{array}$ & $\begin{array}{c}-0.0103 * * * \\
(0.0007)\end{array}$ & $\begin{array}{c}0.0063 * * * \\
(0.0003)\end{array}$ & $\begin{array}{c}0.0146 * * * \\
(0.0004)\end{array}$ \\
\hline Durable & $\begin{array}{c}-0.0144 * * * \\
(0.0004)\end{array}$ & $\begin{array}{c}-0.0041^{* * *} \\
(0.0003)\end{array}$ & $\begin{array}{c}-0.0027 * * * \\
(0.0001)\end{array}$ & $\begin{array}{c}-0.0036 * * * \\
(0.0003)\end{array}$ & $\begin{array}{c}-0.0029 * * * \\
(0.0003)\end{array}$ & $\begin{array}{c}0.0063 * * * \\
(0.0003)\end{array}$ & $\begin{array}{c}0.0135 * * * \\
(0.0005)\end{array}$ & $\begin{array}{c}0.0081^{* * *} \\
(0.0004)\end{array}$ \\
\hline Others & $\begin{array}{c}-0.0207 * * * \\
(0.0005)\end{array}$ & $\begin{array}{c}-0.0186 * * * \\
(0.0005)\end{array}$ & $\begin{array}{c}-0.0054 * * * \\
(0.0001)\end{array}$ & $\begin{array}{c}-0.0072 * * * \\
(0.0003)\end{array}$ & $\begin{array}{c}0.0042 * * * \\
(0.0004)\end{array}$ & $\begin{array}{c}0.0146 * * * \\
(0.0004)\end{array}$ & $\begin{array}{c}0.0081^{* * *} \\
(0.0004)\end{array}$ & $\begin{array}{c}0.0251^{* * *} \\
(0.0009)\end{array}$ \\
\hline \multicolumn{9}{|c|}{ Polynomial Coefficients $\left(b_{i r}\right)$} \\
\hline $\mathrm{v}^{0}$ & $\begin{array}{c}-0.6401 * * * \\
(0.3252)\end{array}$ & $\begin{array}{c}-6.4856 * * * \\
(0.585)\end{array}$ & $\begin{array}{c}-0.1453 * * * \\
(0.1088)\end{array}$ & $\begin{array}{c}1.0447 * * * \\
(0.1055)\end{array}$ & $\begin{array}{c}-1.0662 * * * \\
(0.0008)\end{array}$ & $\begin{array}{c}4.2046 * * * \\
(0.6031)\end{array}$ & $\begin{array}{c}0.548 * * * \\
(0.3681)\end{array}$ & $\begin{array}{c}3.5399 * * * \\
(0.3762)\end{array}$ \\
\hline $\mathrm{v}^{1}$ & $\begin{array}{c}0.7228 * * * \\
(0.2146)\end{array}$ & $\begin{array}{c}5.6947 * * * \\
(0.3688)\end{array}$ & $\begin{array}{c}0.1887 * * * \\
(0.0438)\end{array}$ & $\begin{array}{c}-0.6991 * * * \\
(0.0939)\end{array}$ & $\begin{array}{c}0.7846 * * * \\
(0.1345)\end{array}$ & $\begin{array}{c}-3.2569 * * * \\
(0.3812)\end{array}$ & $\begin{array}{c}-0.4071 * * * \\
(0.1479)\end{array}$ & $\begin{array}{c}-3.0276 * * * \\
(0.4077)\end{array}$ \\
\hline $\mathrm{v}^{2}$ & $\begin{array}{c}-0.2193 * * * \\
(0.0618)\end{array}$ & $\begin{array}{c}-1.7009 * * * \\
(0.1041)\end{array}$ & $\begin{array}{c}-0.0653 * * * \\
(0.0126)\end{array}$ & $\begin{array}{c}0.1824^{* * *} \\
(0.0268)\end{array}$ & $\begin{array}{c}-0.1948 * * * \\
(0.038)\end{array}$ & $\begin{array}{c}0.9381^{* * *} \\
(0.1109)\end{array}$ & $\begin{array}{c}0.1186 * * * \\
(0.0422)\end{array}$ & $\begin{array}{c}0.9412 * * * \\
(0.1182)\end{array}$ \\
\hline $\mathrm{v}^{3}$ & $\begin{array}{c}0.0277 * * * \\
(0.0078)\end{array}$ & $\begin{array}{c}0.2141^{* * *} \\
(0.0129)\end{array}$ & $\begin{array}{c}0.009 * * * \\
(0.0016)\end{array}$ & $\begin{array}{c}-0.0212 * * * \\
(0.0034)\end{array}$ & $\begin{array}{c}0.021 * * * \\
(0.0047)\end{array}$ & $\begin{array}{c}-0.1164 * * * \\
(0.0142)\end{array}$ & $\begin{array}{c}-0.0135 * * \\
(0.0053)\end{array}$ & $\begin{array}{c}-0.1207^{* * *} \\
(0.015)\end{array}$ \\
\hline$v^{4}$ & $\begin{array}{c}-0.0014 * * * \\
(0.0004)\end{array}$ & $\begin{array}{c}-0.0098 * * * \\
(0.0006)\end{array}$ & $\begin{array}{c}-0.0004^{* * *} \\
(0.0001)\end{array}$ & $\begin{array}{c}0.0009 * * * \\
(0.0002)\end{array}$ & $\begin{array}{c}-0.0008 * * * \\
(0.0002)\end{array}$ & $\begin{array}{c}0.0054^{* * *} \\
(0.0007)\end{array}$ & $\begin{array}{c}0.0005 * * \\
(0.0002)\end{array}$ & $\begin{array}{c}0.0057 * * * \\
(0.0007)\end{array}$ \\
\hline
\end{tabular}


Table A3 (cont'd): Main estimated coefficients for the estimated EASI demand system (1')

\begin{tabular}{|c|c|c|c|c|c|c|c|c|}
\hline & Food & Housing & Electricity & Heating & Transport & Service & Durable & Others \\
\hline \multicolumn{9}{|c|}{ Indirect utility interaction with socioeconomic coefficients $\left(d_{i k}\right)$} \\
\hline $\mathrm{Z}_{1}$ & $\begin{array}{c}0.0028 * * * \\
(0.0001)\end{array}$ & $\begin{array}{c}-0.0023^{* * *} \\
(0.0002)\end{array}$ & $\begin{array}{c}0.0003^{* * *} \\
(0.000)\end{array}$ & $\begin{array}{c}-0.0005 * * * \\
(0.0001)\end{array}$ & $\begin{array}{c}0.0039 * * * \\
(0.0001)\end{array}$ & $\begin{array}{c}-0.003^{* * *} \\
(0.0002)\end{array}$ & $\begin{array}{c}0.0005^{* * *} \\
(0.0001)\end{array}$ & $\begin{array}{c}-0.0017^{* * *} \\
(0.0002)\end{array}$ \\
\hline $\mathrm{Z}_{2}$ & $\begin{array}{c}-0.0103 * * * \\
(0.0002)\end{array}$ & $\begin{array}{c}0.0051^{* * *} \\
(0.0002)\end{array}$ & $\begin{array}{c}-0.0008 * * * \\
(0.000)\end{array}$ & $\begin{array}{c}0.0004^{* * *} \\
(0.0001)\end{array}$ & $\begin{array}{c}-0.0008 * * * \\
(0.0001)\end{array}$ & $\begin{array}{c}0.0017 * * * \\
(0.0002)\end{array}$ & $\begin{array}{c}-0.001 * * * \\
(0.0001)\end{array}$ & $\begin{array}{c}0.0057 * * * \\
(0.0003)\end{array}$ \\
\hline $\mathrm{Z}_{3}$ & $\begin{array}{c}-0.0106 * * * \\
(0.0001)\end{array}$ & $\begin{array}{c}0.0049 * * * \\
(0.0002)\end{array}$ & $\begin{array}{c}-0.0011^{* * *} \\
(0.000)\end{array}$ & $\begin{array}{c}-0.0006 * * * \\
(0.0001)\end{array}$ & $\begin{array}{c}0.0025 * * * \\
(0.0001)\end{array}$ & $\begin{array}{c}-0.0016 * * * \\
(0.0002)\end{array}$ & $\begin{array}{l}-0.0001 \\
(0.0001)\end{array}$ & $\begin{array}{c}0.0066 * * * \\
(0.0003)\end{array}$ \\
\hline $\mathrm{Z}_{5}$ & $\begin{array}{l}-0.0001 \\
(0.0002)\end{array}$ & $\begin{array}{c}0.0003 \\
(0.0002)\end{array}$ & $\begin{array}{c}-0.0001^{* *} \\
(0.000)\end{array}$ & $\begin{array}{c}0.0004^{* * *} \\
(0.0001)\end{array}$ & $\begin{array}{c}-0.0019 * * * \\
(0.0001)\end{array}$ & $\begin{array}{c}0.0012 * * * \\
(0.0002)\end{array}$ & $\begin{array}{c}-0.0013 * * * \\
(0.0001)\end{array}$ & $\begin{array}{c}0.0015 * * * \\
(0.0002)\end{array}$ \\
\hline $\mathrm{Z}_{6}$ & $\begin{array}{c}0.0008 * * * \\
(0.0001)\end{array}$ & $\begin{array}{c}-0.0005 * * * \\
(0.0002)\end{array}$ & $\begin{array}{c}0 \\
(0.000)\end{array}$ & $\begin{array}{c}-0.0007 * * * \\
(0.0001)\end{array}$ & $\begin{array}{c}0.0023^{* * *} * \\
(0.0001)\end{array}$ & $\begin{array}{c}-0.0031 * * * \\
(0.0002)\end{array}$ & $\begin{array}{c}0.0006^{* * * *} \\
(0.0001)\end{array}$ & $\begin{array}{c}0.0007 * * * \\
(0.0002)\end{array}$ \\
\hline $\mathrm{Z}_{7}$ & $\begin{array}{c}0.0045 * * * \\
(0.0001)\end{array}$ & $\begin{array}{c}-0.0024 * * * \\
(0.0002)\end{array}$ & $\begin{array}{c}0.0002 * * * \\
(0.000)\end{array}$ & $\begin{array}{c}-0.0009 * * * \\
(0.0001)\end{array}$ & $\begin{array}{c}0.0024^{* * *} \\
(0.0001)\end{array}$ & $\begin{array}{c}-0.0028 * * * \\
(0.0002)\end{array}$ & $\begin{array}{l}0.001 * * * \\
(0.0001)\end{array}$ & $\begin{array}{c}-0.0021^{* * *} \\
(0.0002)\end{array}$ \\
\hline $\mathrm{Z}_{8}$ & $0.0074 * * *$ & $-0.0041 * * *$ & $0.0004 * * *$ & $-0.0011 * * *$ & $0.0023 * * *$ & $-0.0033 * * *$ & $0.0013 * * *$ & $-0.0029 * * *$ \\
\hline $\mathrm{R}^{2}$ & 0.3641 & 0.2336 & 0.2047 & 0.1020 & 0.1080 & 0.1640 & 0.1432 & 0.1563 \\
\hline Observations & 120,913 & & & & & & & \\
\hline
\end{tabular}

Key: Significance levels $*(\mathrm{p}<0.10),{ }^{* *}(\mathrm{p}<0.05), * * *(\mathrm{p}<0.01)$. Bootstrap standard errors in brackets. These regressions also contain controls (not reported): dummies for central heating, building date 1948, building date 19491990, populations below 20,000, between 20,000-100,000 and more than 100,000 inhabitants, the quarter and year of the survey, and dwelling size (squared meters). For Indirect utility interaction with socioeconomic coefficients $\left(d_{i k}\right)$, Single parents with dependent children $\left(\mathrm{z}_{4}\right)$ are the base category. 
For example, to obtain the expenditure elasticities we make use of

(A2) $\frac{\partial w_{h i}}{\partial y_{h}}=K_{i} \frac{\partial \log v_{h}}{\partial \log y_{h}}$ with $K_{i} \equiv \sum_{r=0}^{R} b_{i r} r \log \left(v_{h}\right)^{r-1}+\sum_{k=1}^{K} d_{i k} z_{h k}$,

where $\frac{\partial \log v_{h}}{\partial \log y_{h}}=1-\sum_{j=1}^{I} \log \left(q_{j}\right) \frac{\partial w_{h j}}{\partial y_{h}}$ and $\frac{\partial w_{h i}}{\partial \log y_{h}}=\frac{K_{i}}{1+\sum_{i=1}^{I} K_{i} q_{i}}$. We then obtain

(A3) $\varepsilon_{h, i y}=\frac{K_{i}}{1+\sum_{i=1}^{I} K_{i} q_{i}} \frac{1}{w_{h i}}+1$

Lewbel and Pendakur (2009) defined compensated semi-price elasticities by $\frac{\partial w * h i}{\partial \log \left(q_{j h}\right)}=a_{i j}$, where $a_{i j}$ is the commodity price parameters obtained directly from the estimated demand system and $w * h i$ is the estimated budget share. Using the Slutsky equation, the authors shows that uncompensated semi-elasticities can be obtained from $\frac{\partial w_{h i}}{\partial \log \left(q_{i h}\right)}=a_{i j}-\frac{\partial w_{h i}}{\partial \log \left(y_{h}\right)} w_{h j}$. Consequently, the uncompensated price elasticities are obtained as $\varepsilon_{h, i j}=\frac{1}{w_{h i}} *\left(a_{i j}-\frac{K_{i}}{1+\sum_{i=1}^{I} K_{i} q_{i}} * w_{h j}\right)$ for $i \neq j$ and $\varepsilon_{i i}=\frac{1}{w_{h i}} *\left(a_{i i}-\frac{K_{i}}{1+\sum_{i=1}^{I} K_{i} q_{i}} * w_{h i}\right)-1$ for $i=j$.

Table A.4: Own and cross price elasticities for first total expenditure quartile

\begin{tabular}{|c|c|c|c|c|c|c|c|c|}
\hline$\Delta \% \mathrm{x}$ & Food & Housing & Electricity & Heating & Transport & Service & Durable & Other \\
\hline Food & $\begin{array}{c}-0.616^{* * *} \\
(0.004)\end{array}$ & $\begin{array}{c}-0.007 * * \\
(0.003)\end{array}$ & $\begin{array}{c}0.006^{* * * *} \\
(0.001)\end{array}$ & $\begin{array}{c}0.019 * * * \\
(0.002)\end{array}$ & $\begin{array}{c}0.022 * * * \\
(0.002)\end{array}$ & $\begin{array}{c}-0.017^{* * *} \\
(0.003)\end{array}$ & $\begin{array}{c}-0.057 * * * \\
(0.002)\end{array}$ & $\begin{array}{c}-0.052 * * * \\
(0.003)\end{array}$ \\
\hline Housing & $\begin{array}{c}0.033^{* * *} \\
(0.002)\end{array}$ & $\begin{array}{c}-0.707 * * * \\
(0.002)\end{array}$ & $\begin{array}{c}0.009 * * * \\
0.000\end{array}$ & $\begin{array}{c}0.03^{* * *} \\
(0.001)\end{array}$ & $\begin{array}{c}0.023 * * * \\
(0.001)\end{array}$ & $\begin{array}{c}0.057 * * * \\
(0.001)\end{array}$ & $\begin{array}{c}0.016 * * * \\
(0.001)\end{array}$ & $\begin{array}{c}0.03^{* * *} \\
(0.002)\end{array}$ \\
\hline Electricity & $\begin{array}{c}0.069 * * * \\
(0.007)\end{array}$ & $\begin{array}{c}0.08^{* * *} \\
(0.003)\end{array}$ & $\begin{array}{c}-0.446^{* * *} \\
(0.012)\end{array}$ & $\begin{array}{c}-0.072 * * * \\
(0.005)\end{array}$ & $\begin{array}{c}0.015^{* * *} \\
(0.004)\end{array}$ & $\begin{array}{c}-0.034^{* * *} \\
(0.003)\end{array}$ & $\begin{array}{c}-0.059 * * * \\
(0.004)\end{array}$ & $\begin{array}{c}-0.087^{* * *} \\
(0.004)\end{array}$ \\
\hline Heating & $\begin{array}{c}0.065^{* * *} \\
(0.006)\end{array}$ & $\begin{array}{c}0.107 * * * \\
(0.005)\end{array}$ & $\begin{array}{c}-0.05 * * * \\
(0.003)\end{array}$ & $\begin{array}{c}-0.706 * * * \\
(0.007)\end{array}$ & $\begin{array}{c}-0.012 * * * \\
(0.004)\end{array}$ & $\begin{array}{c}0.004 \\
(0.005)\end{array}$ & $\begin{array}{c}-0.055^{* * *} \\
(0.006)\end{array}$ & $\begin{array}{c}-0.091^{* * *} \\
(0.005)\end{array}$ \\
\hline Transport & $\begin{array}{c}0.004 \\
(0.005)\end{array}$ & $\begin{array}{c}-0.046 * * * \\
(0.003)\end{array}$ & $\begin{array}{c}-0.007^{* * *} \\
(0.001)\end{array}$ & $\begin{array}{c}-0.016 * * * \\
(0.002)\end{array}$ & $\begin{array}{c}-0.861^{* * *} \\
(0.004)\end{array}$ & $\begin{array}{c}-0.03^{* * *} \\
(0.004)\end{array}$ & $\begin{array}{c}-0.027 * * * \\
(0.003)\end{array}$ & $\begin{array}{c}0.061^{* * *} \\
(0.004)\end{array}$ \\
\hline Service & $\begin{array}{c}-0.251^{* * *} \\
(0.007)\end{array}$ & $\begin{array}{c}-0.193 * * * \\
(0.006)\end{array}$ & $\begin{array}{c}-0.052^{* * *} \\
(0.001)\end{array}$ & $\begin{array}{c}-0.053 * * * \\
(0.003)\end{array}$ & $\begin{array}{c}-0.111^{* * *} \\
(0.004)\end{array}$ & $\begin{array}{c}-1.188^{* * *} \\
(0.008)\end{array}$ & $\begin{array}{c}0.023^{* * *} \\
(0.004)\end{array}$ & $\begin{array}{c}0.019 * * * \\
(0.005)\end{array}$ \\
\hline Durable & $\begin{array}{c}-0.3^{* * *} \\
(0.007)\end{array}$ & $\begin{array}{c}-0.167 * * * \\
(0.006)\end{array}$ & $\begin{array}{c}-0.055^{* * *} \\
(0.002)\end{array}$ & $\begin{array}{c}-0.076 * * * \\
(0.005)\end{array}$ & $\begin{array}{c}-0.077^{* * *} \\
(0.004)\end{array}$ & $\begin{array}{c}0.074 * * * \\
(0.006)\end{array}$ & $\begin{array}{c}-0.799 * * * \\
(0.008)\end{array}$ & $\begin{array}{c}0.071^{* * *} \\
(0.006)\end{array}$ \\
\hline Other & $\begin{array}{c}-0.267^{* * *} \\
(0.003)\end{array}$ & $\begin{array}{c}-0.343 * * * \\
(0.003)\end{array}$ & $\begin{array}{c}-0.055^{* * *} \\
(0.001)\end{array}$ & $\begin{array}{c}-0.08 * * * \\
(0.001)\end{array}$ & $\begin{array}{c}-0.05^{* * *} \\
(0.002)\end{array}$ & $\begin{array}{c}0.008^{* * *} \\
(0.002)\end{array}$ & $\begin{array}{c}-0.006^{* * *} \\
(0.002)\end{array}$ & $\begin{array}{c}-1.016^{* * *} \\
(0.005)\end{array}$ \\
\hline
\end{tabular}

Key: Significance levels $*(\mathrm{p}<0.10), * *(\mathrm{p}<0.05), * * *(\mathrm{p}<0.01)$. Bootstrap standard errors in brackets. Elasticities are evaluated at the mean budget shares for households at the first total expenditure quartile. 
Table A.5: Own and cross price elasticities for the last total expenditure quartile

\begin{tabular}{|c|c|c|c|c|c|c|c|c|}
\hline$\Delta \% \mathrm{q}$ & Food & Housing & Electricity & Heating & Transport & Service & Durable & Other \\
\hline Food & $\begin{array}{c}-0.526 * * * \\
(0.004)\end{array}$ & $\begin{array}{c}-0.010^{* * *} \\
(0.003)\end{array}$ & $\begin{array}{c}0.007 * * * \\
(0.001)\end{array}$ & $\begin{array}{c}0.024 * * * \\
(0.002)\end{array}$ & $\begin{array}{c}0.030 * * * \\
(0.003)\end{array}$ & $\begin{array}{c}-0.009 * * * \\
(0.003)\end{array}$ & $\begin{array}{c}-0.053^{* * *} \\
(0.002)\end{array}$ & $\begin{array}{c}-0.008^{* *} \\
(0.003)\end{array}$ \\
\hline Housing & $\begin{array}{c}0.002 \\
(0.002)\end{array}$ & $\begin{array}{c}-0.699 * * * \\
(0.003)\end{array}$ & $\begin{array}{c}0.003^{* * *} \\
(0.000)\end{array}$ & $\begin{array}{c}0.025^{* * *} \\
(0.001)\end{array}$ & $\begin{array}{c}0.015^{* * *} \\
(0.001)\end{array}$ & $\begin{array}{c}0.070 * * * \\
(0.002)\end{array}$ & $\begin{array}{c}0.028 * * * \\
(0.001)\end{array}$ & $\begin{array}{c}0.065^{* * *} \\
(0.002)\end{array}$ \\
\hline Electricity & $\begin{array}{c}0.086^{* * *} \\
(0.008)\end{array}$ & $\begin{array}{c}0.080^{* * * *} \\
(0.004)\end{array}$ & $\begin{array}{c}-0.194 * * * \\
(0.014)\end{array}$ & $\begin{array}{c}-0.117^{* * *} \\
(0.006)\end{array}$ & $\begin{array}{c}0.014 * * * \\
(0.005)\end{array}$ & $\begin{array}{c}-0.042^{* * *} \\
(0.004)\end{array}$ & $\begin{array}{c}-0.058^{* * *} \\
(0.004)\end{array}$ & $\begin{array}{c}-0.066 * * * \\
(0.005)\end{array}$ \\
\hline Heating & $\begin{array}{c}0.110^{* * *} \\
(0.008)\end{array}$ & $\begin{array}{c}0.169 * * * \\
(0.006)\end{array}$ & $\begin{array}{c}-0.070^{* * *} \\
(0.004)\end{array}$ & $\begin{array}{c}-0.609 * * * \\
(0.008)\end{array}$ & $\begin{array}{l}-0.004 \\
(0.005)\end{array}$ & $\begin{array}{c}0.023^{* * *} \\
(0.006)\end{array}$ & $\begin{array}{c}-0.038^{* * *} \\
(0.007)\end{array}$ & $\begin{array}{c}-0.049 * * * \\
(0.006)\end{array}$ \\
\hline Transport & $\begin{array}{c}0.017^{* * *} \\
(0.005)\end{array}$ & $\begin{array}{c}-0.031^{* * *} \\
(0.003)\end{array}$ & $\begin{array}{c}-0.007^{* * *} \\
(0.001)\end{array}$ & $\begin{array}{c}-0.015^{* * *} \\
(0.002)\end{array}$ & $\begin{array}{c}-0.841^{* * *} \\
(0.004)\end{array}$ & $\begin{array}{c}-0.019 * * * \\
(0.004)\end{array}$ & $\begin{array}{c}-0.015^{* * *} \\
(0.003)\end{array}$ & $\begin{array}{c}0.105^{* * *} \\
(0.004)\end{array}$ \\
\hline Service & $\begin{array}{c}-0.203^{* * *} \\
(0.006)\end{array}$ & $\begin{array}{c}-0.145^{* * *} \\
(0.006)\end{array}$ & $\begin{array}{c}-0.041^{* * *} \\
(0.001)\end{array}$ & $\begin{array}{c}-0.041^{* * *} \\
(0.003)\end{array}$ & $\begin{array}{c}-0.094 * * * \\
(0.004)\end{array}$ & $\begin{array}{c}-1.184^{* * *} \\
(0.008)\end{array}$ & $\begin{array}{c}-0.011^{* * *} \\
(0.004)\end{array}$ & $\begin{array}{c}-0.073^{* * *} \\
(0.005)\end{array}$ \\
\hline Durable & $\begin{array}{c}-0.182^{* * *} \\
(0.006)\end{array}$ & $\begin{array}{c}-0.086^{* * *} \\
(0.005)\end{array}$ & $\begin{array}{c}-0.032^{* * *} \\
(0.002)\end{array}$ & $\begin{array}{c}-0.041^{* * *} \\
(0.005)\end{array}$ & $\begin{array}{c}-0.041^{* * *} \\
(0.004)\end{array}$ & $\begin{array}{c}0.051^{* * *} \\
(0.005)\end{array}$ & $\begin{array}{c}-0.871^{* * *} \\
(0.007)\end{array}$ & $\begin{array}{c}0.048^{* * *} \\
(0.006)\end{array}$ \\
\hline Other & $\begin{array}{c}-0.158^{* * *} \\
(0.003)\end{array}$ & $\begin{array}{c}-0.202^{* * *} \\
(0.003)\end{array}$ & $\begin{array}{c}-0.032 * * * \\
(0.001)\end{array}$ & $\begin{array}{c}-0.047^{* * *} \\
(0.001)\end{array}$ & $\begin{array}{c}-0.029 * * * \\
(0.002)\end{array}$ & $\begin{array}{l}-0.003 \\
(0.002) \\
\end{array}$ & $\begin{array}{c}-0.020 * * * \\
(0.002)\end{array}$ & $\begin{array}{c}-1.062 * * * \\
(0.004) \\
\end{array}$ \\
\hline
\end{tabular}

Key: Significance levels $*(\mathrm{p}<0.10), * *(\mathrm{p}<0.05), * * *(\mathrm{p}<0.01)$. Bootstrap standard errors in brackets. Elasticities are evaluated at the mean budget shares for households at the last total expenditure quartile.

Table A.6: Expenditure elasticities for total expenditures quartiles

\begin{tabular}{|c|cccccccc|}
\hline \multirow{2}{*}{ 1st } & \multicolumn{1}{c}{ Food } & Housing & Electricity & Heating & Transport & Service & Durable & Other \\
\cline { 2 - 8 } & $0.701^{* * *}$ & $0.509^{* * *}$ & $0.535^{* * *}$ & $0.738^{* * *}$ & $0.921^{* * *}$ & $1.805^{* * *}$ & $1.33^{* * *}$ & $1.809^{* * *}$ \\
& $(0.004)$ & $(0.003)$ & $(0.005)$ & $(0.006)$ & $(0.005)$ & $(0.012)$ & $(0.007)$ & $(0.007)$ \\
\multirow{3}{*}{ 2nd } & $0.655^{* * *}$ & $0.452^{* * *}$ & $0.449 * * *$ & $0.658^{* * *}$ & $0.888^{* * *}$ & $1.856^{* * *}$ & $1.289^{* * *}$ & $1.705^{* * *}$ \\
& $(0.004)$ & $(0.004)$ & $(0.004)$ & $(0.007)$ & $(0.005)$ & $(0.011)$ & $(0.007)$ & $(0.006)$ \\
& $0.606^{* * *}$ & $0.424^{* * *}$ & $0.377^{* * *}$ & $0.597^{* * *}$ & $0.861^{* * *}$ & $1.899^{* * *}$ & $1.253^{* * *}$ & $1.66^{* * *}$ \\
\multirow{3}{*}{ 4th } & $(0.004)$ & $(0.004)$ & $(0.006)$ & $(0.009)$ & $(0.006)$ & $(0.012)$ & $(0.006)$ & $(0.005)$ \\
& $0.532^{* * *}$ & $0.483^{* * *}$ & $0.299^{* * *}$ & $0.472^{* * *}$ & $0.816^{* * *}$ & $1.798^{* * *}$ & $1.15^{* * *}$ & $1.56^{* * *}$ \\
& $(0.007)$ & $(0.006)$ & $(0.009)$ & $(0.014)$ & $(0.008)$ & $(0.015)$ & $(0.007)$ & $(0.007)$ \\
\hline
\end{tabular}

Key: Significance levels $*(\mathrm{p}<0.10), * *(\mathrm{p}<0.05), * * *(\mathrm{p}<0.01)$. Bootstrap standard errors in brackets. Elasticities are evaluated at the mean budget shares for households in the relevant quartile. 
Table A.7 presents the econometric estimates of labour supply.

Table A7: Econometric estimate of the labour supply function (8)

\begin{tabular}{|lc|}
\hline \multicolumn{2}{|c|}{ Dependent variable log(working hours) } \\
\hline Frischian wage elasticity & $0.648^{* * *}$ \\
& $(0.03)$ \\
Inverse Mills Ratio & $-0.224^{* * *}$ \\
& $(0.022)$ \\
Rural & $0.041^{* * *}$ \\
& $(0.007)$ \\
Male head of household & $-0.029^{* * *}$ \\
& $(0.008)$ \\
Dependent children & -0.003 \\
& $(0.008)$ \\
One-member household & $-0.433^{* * *}$ \\
& $(0.006)$ \\
Constant & $7.42^{* * *}$ \\
& $(0.045)$ \\
R-squared & 0.4406 \\
Observations & 30,894 \\
\hline
\end{tabular}

Key: Significance levels $*(\mathrm{p}<0.10), * *(\mathrm{p}<0.05), * * *(\mathrm{p}<0.01)$. Bootstrap standard errors in brackets. 


\section{Appendix B: More details on equivalent variations}

Figure B.1: Equivalent variations in $€$ per year, relative to consumption expenditure

(a) Carbon tax of $€ 50 / \mathrm{tCO}_{2}$

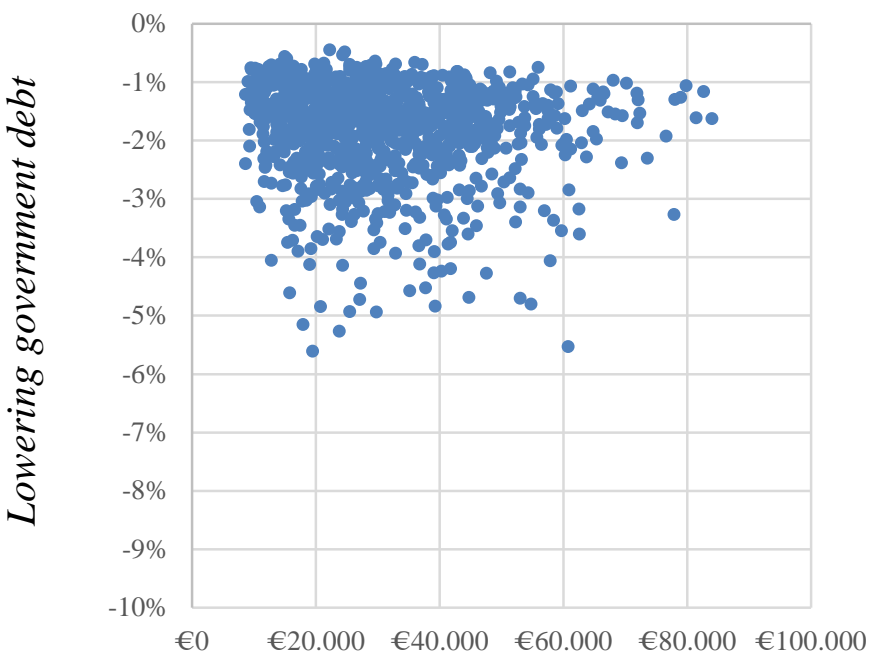

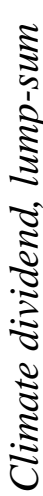
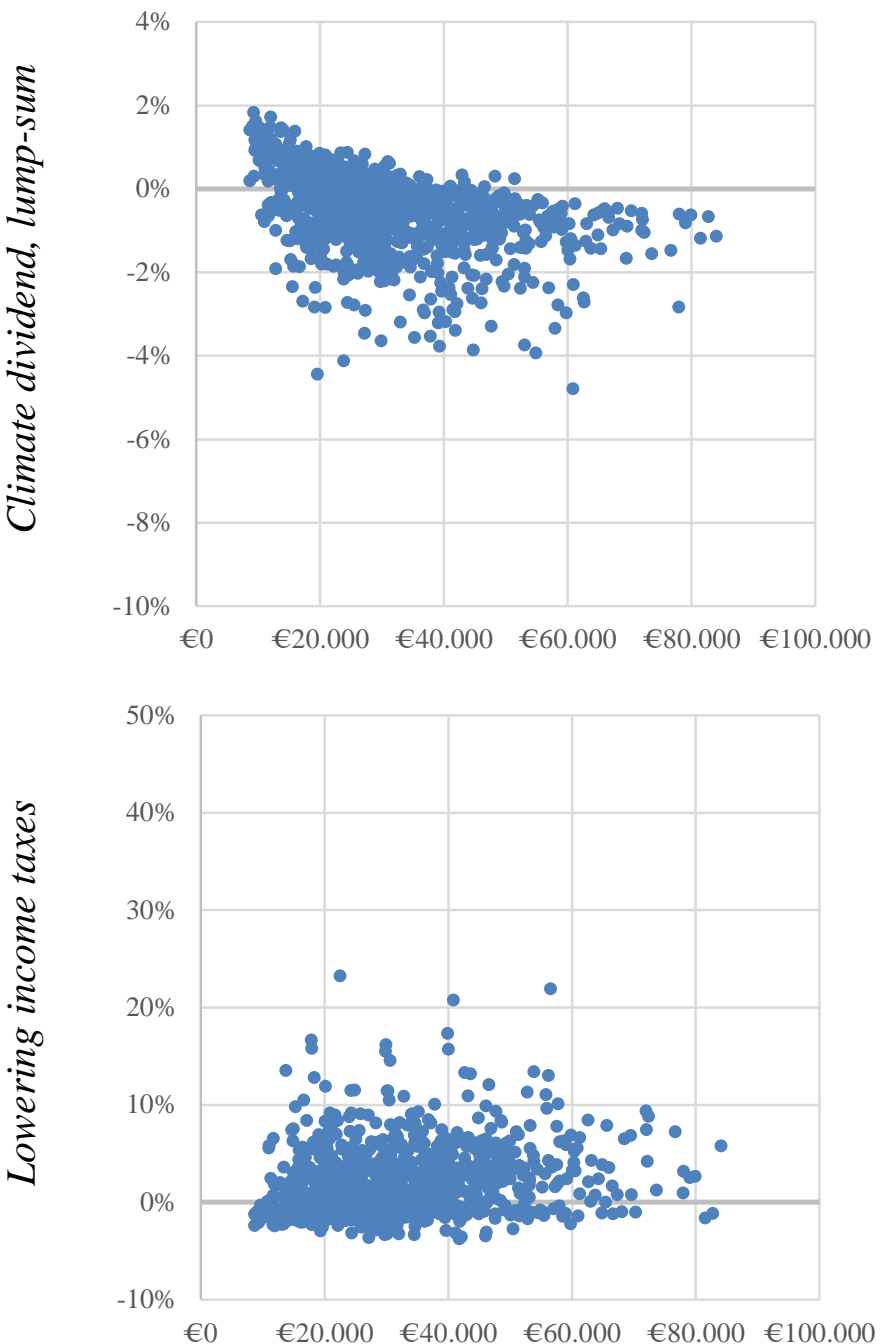

(b) $39 \%$ reduction in $\mathrm{CO}_{2}$ emissions
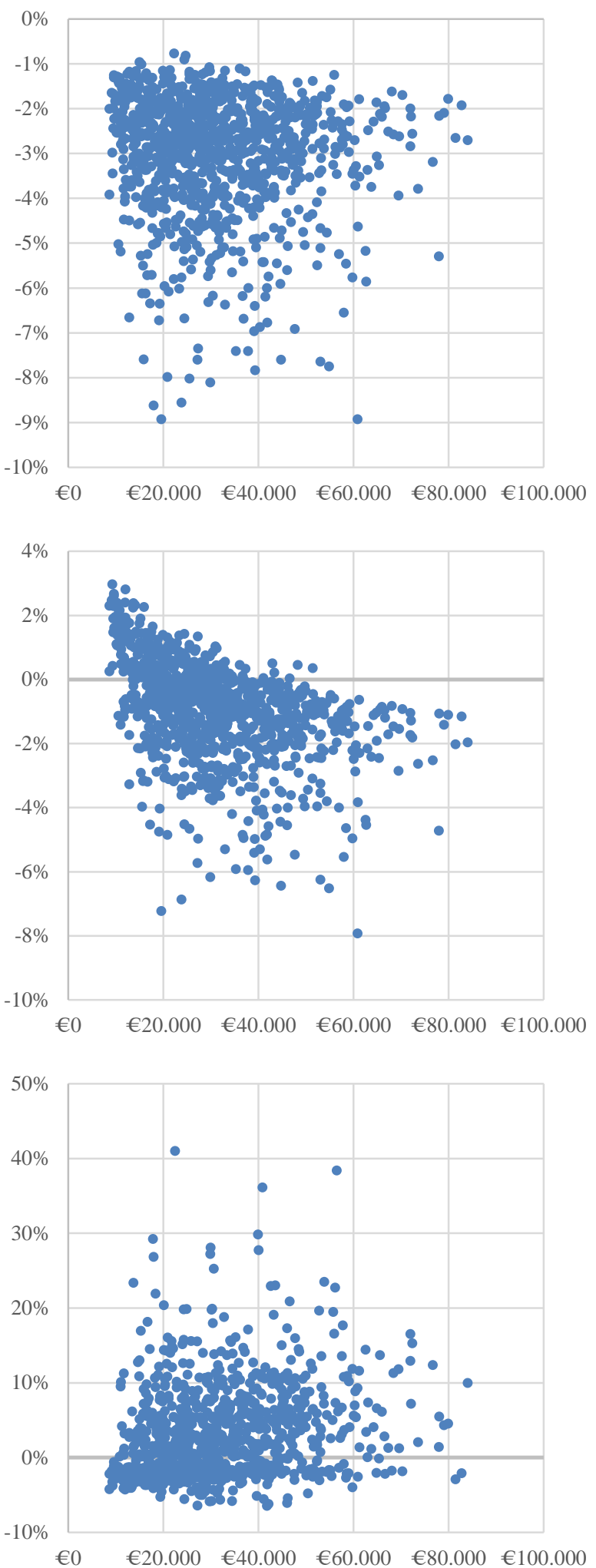
Figure B.2: Equivalent variations across taxable incomes in $€$ per year

(a) Carbon tax of $€ 50 / \mathrm{tCO}_{2}$
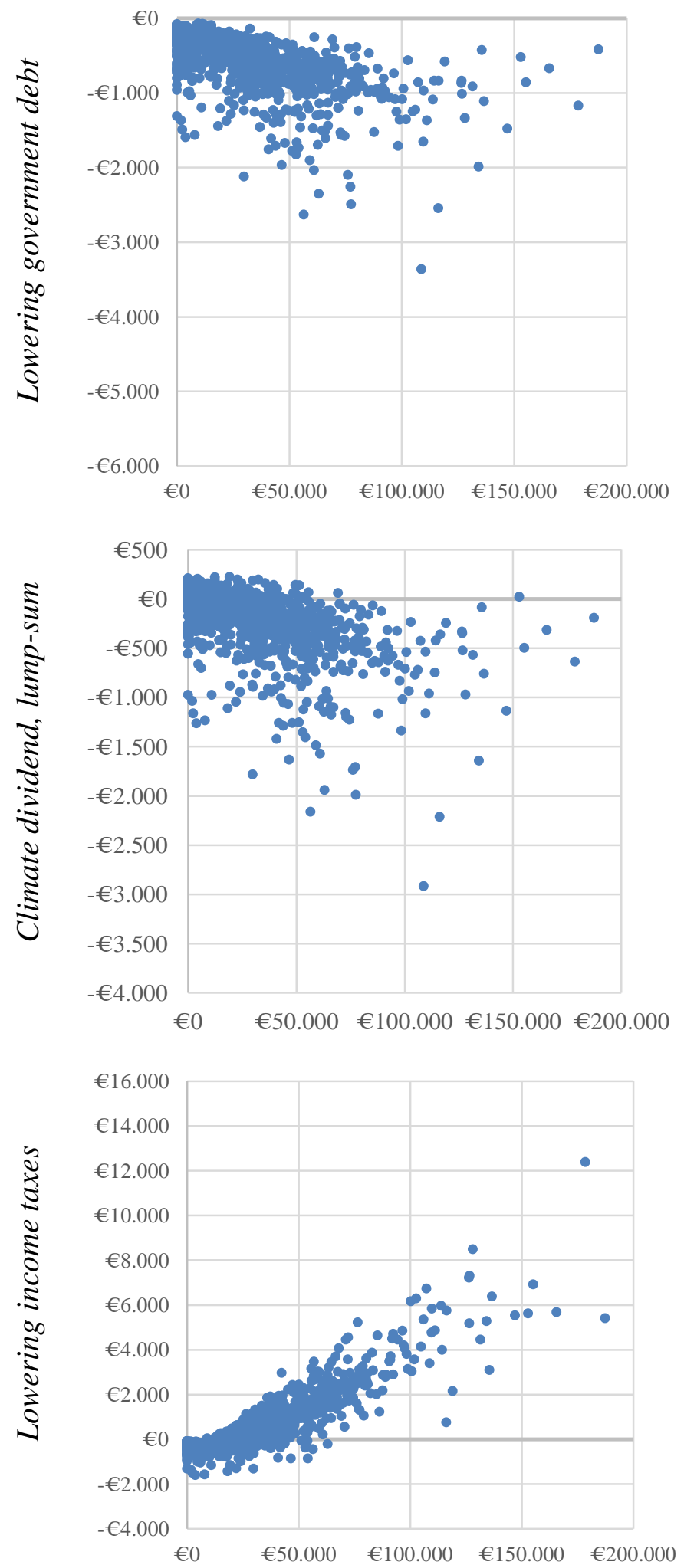

(b) $39 \%$ reduction in $\mathrm{CO}_{2}$ emissions
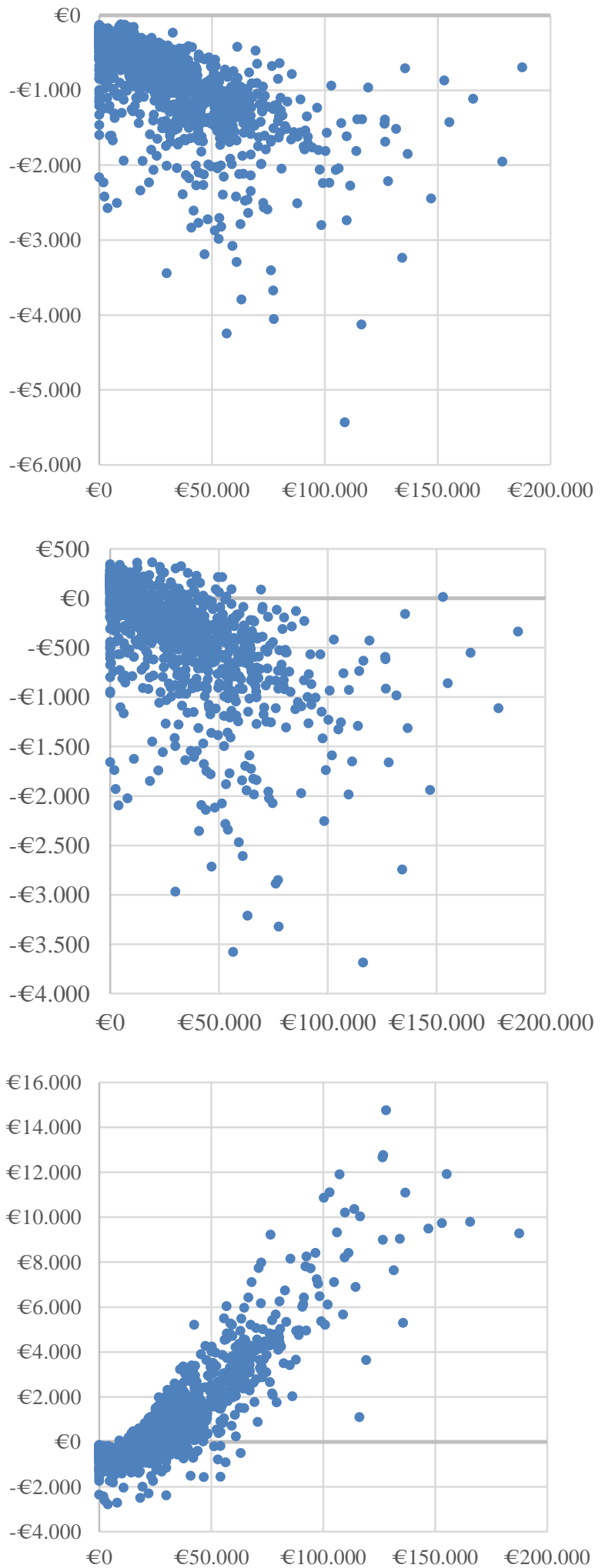


\section{Appendix C: Numerical solution routine}

We use the optimisation software GAMS and its CONOPT3 solver to conduct our policy experiments discussed in section 4. Using the no-policy case as an initial point, the solver has no difficulty in finding the new equilibrium for given policy changes in a robust and efficient manner. Our GAMS code is available upon request and here we summarize the set of simultaneous equations. Given prices, policy parameters $\{\lambda, \pi, s\}$, and the tax policy function $T_{h}($.$) , equilibrium choices for each household are given by equations (6), (8), (1) and (2) or$

(C1) $\quad y_{h}+\sigma_{h}+T\left(W_{h} l_{h}+\bar{y}_{h}\right)=W_{h} l_{h}+\bar{y}_{h}+s \varsigma_{h}$,

(C2) $l_{h}=\left(\frac{1}{\phi_{h}} \frac{\left(1-t_{h}\right) W_{h}}{P_{h}^{M}}\right)^{\varepsilon^{F}}$,

$$
\begin{aligned}
& w_{h i}=\sum_{r=0}^{R} b_{i r} \log \left(v_{h}\right)^{r}+\sum_{j=1}^{I} a_{i j} \log \left(q_{h i}\right)+\sum_{k=1}^{K}\left[d_{i k} z_{h k} \log \left(v_{h}\right)+g_{i k} z_{h k}\right], \text { and } \\
& \log \left(v_{h}\right)=\log \left(y_{h}\right)-\sum_{j=1}^{I} w_{h j} \log \left(q_{h j}\right)+\frac{1}{2} \sum_{i=1}^{I} \sum_{j=1}^{I} a_{i j} \log \left(q_{h i}\right) \log \left(q_{h j}\right) .
\end{aligned}
$$

Note that (C3) defines the budget share for each household and each of the goods (except the last one due to Walras' law). In total, this gives 11 equations per household and 11,000 equations for all 1000 households. The government must meet its budget constraint (11) or

$$
\lambda \sum_{h=1}^{H} N_{h} T_{h}\left(W_{h} l_{h}+\bar{y}_{h}\right)+\pi E=M+\sum_{h=1}^{H} N_{h} \varsigma_{h} S .
$$

The price of each good follows from (9) or

$$
\vec{q}_{h}=\vec{p}_{h}+\pi(1-\rho) \vec{e}_{h} \text { with } \rho=(\pi / \beta)^{\varepsilon} \text {. }
$$

Aggregate emissions follow from (10) or

$$
E=\sum_{h=1}^{H} N_{h}(1-\rho) \vec{e}_{h}{ }^{\prime} \vec{x}_{h}\left(\vec{q}_{h}, y_{h}\right)
$$

The solver routine must solve at least 11,010 simultaneous equations for our policy experiments of a given carbon tax discussed in section 4.1. Our GAMS code includes additional equations for intermediate variables such as household emissions, taxable income, the income tax bill, or the marginal prices (5). For the policy simulation exercises of section 4.2 there is an additional restriction to ensure that aggregate emissions (C7) are restricted to the target level. 